\title{
Intensified impact of tropical Atlantic SST on the western North Pacific summer climate under a weakened Atlantic thermohaline circulation
}

Article

Accepted Version

Chen, W., Lee, J.-Y., Lu, R., Dong, B. and Ha, K.-J. (2015) Intensified impact of tropical Atlantic SST on the western North Pacific summer climate under a weakened Atlantic thermohaline circulation. Climate Dynamics, 45 (7-8). pp. 2033-2046. ISSN 1432-0894 doi: https://doi.org/10.1007/s00382-014-2454-4 Available at https://centaur.reading.ac.uk/40528/

It is advisable to refer to the publisher's version if you intend to cite from the work. See Guidance on citing.

Published version at: http://link.springer.com/article/10.1007\%2Fs00382-014-2454-4

To link to this article DOI: http://dx.doi.org/10.1007/s00382-014-2454-4

Publisher: Springer

All outputs in CentAUR are protected by Intellectual Property Rights law, including copyright law. Copyright and IPR is retained by the creators or other copyright holders. Terms and conditions for use of this material are defined in the End User Agreement. 


\section{www.reading.ac.uk/centaur}

\section{CentAUR}

Central Archive at the University of Reading

Reading's research outputs online 


\title{
Intensified Impact of Tropical Atlantic SST on the Western North Pacific Summer Climate Under a Weakened Atlantic Thermohaline Circulation
}

\author{
Wei Chen ${ }^{1}$, June-Yi Lee ${ }^{2}$, Riyu Lu ${ }^{1}$, Buwen Dong ${ }^{3}$ and Kyung-Ja $\mathrm{Ha}^{2,4}$ \\ 1. State Key Laboratory of Numerical Modeling for Atmospheric Sciences and Geophysical Fluid Dynamics, \\ Institute of Atmospheric Physic, Chinese Academy of Sciences, Beijing, China \\ ${ }^{2 .}$ Institute of Environmental Studies, Pusan National University, Busan, Korea \\ 3. National Centre for Atmospheric Science-Climate, Department of Meteorology, University of Reading, \\ Reading, UK \\ ${ }^{4 .}$ Department of Atmospheric Sciences, Pusan National University, Busan, Korea
}

Submitted to Climate Dynamics

Corresponding author:

Dr. Kyung-Ja Ha

Department of Atmospheric Sciences

Pusan National University

Busan, 609-735, Korea

Email:kjha@pusan.ac.kr 
The tropical North Atlantic (TNA) sea surface temperature (SST) has been

3 identified as one of regulators on the boreal summer climate over the western North

4 Pacific (WNP), in addition to SSTs in the tropical Pacific and Indian Oceans. The

5 major physical process previously proposed is that the TNA warming induces a pair

6 of cyclonic circulation anomaly over the eastern Pacific and negative precipitation

7 anomalies over the eastern to central tropical Pacific, which in turn lead to an

8 anticyclonic circulation anomaly over the western to central north Pacific. This study

9 further demonstrates that the modulation of the TNA warming to the WNP summer

10 climate anomaly tends to be intensified under background of the weakened Atlantic

11 thermohaline circulation (THC) by using a water-hosing experiment. The result

12 suggests that the weakened THC induces a decrease in thermocline depth over the

13 TNA region that results in enhanced sensitivity of SST variability to wind anomalies

14 and thus intensification of the interannual variation of TNA SST. Under the weakened

15 THC, the atmospheric responses to the TNA warming are westward shifted,

16 enhancing the anticyclonic circulation and negative precipitation anomaly over the

17 WNP. This result supports the recent finding that the negative phase of the Atlantic

18 multidecadal oscillation (AMO) after the late 1960s has been favourable for the

19 strengthening of the connection between TNA SST variability and WNP summer

20 climate and has important implications for seasonal prediction and future projection 
21 of the WNP summer climate.

22 Key words: western North Pacific (WNP) summer climate; tropical North Atlantic

23 (TNA) SST; weakened Atlantic thermohaline circulation (THC); Atlantic

24 multidecadal oscillation (AMO)

\section{Introduction}

The western North Pacific (WNP) summer climate, as one of the most important components in the Asian summer monsoon system, has been widely studied. The WNP anticyclonic circulation (WNPAC) is closely related with the East Asian monsoon in subseasonal to seasonal time scales (Kosaka et al. 2013; Lee et al. 2013; Moon et al. 2013; Wang et al. 2014) and tropical storm (Wang et al. 2013). Thus,

31 better understanding of the WNPAC variability is of particular importance in understanding the Asian summer monsoon system that is the most difficult challenge in seasonal climate prediction (e.g., Kang et al. 2004; Wang et al. 2004, 2009, 2014; Lee et al. 2010, 2011b; Kosaka et al. 2012; Sohn et al. 2012 and many others). The WNPAC variability is mainly influenced by the El Niño Southern Oscillation (ENSO; e.g., Chang et al. 2000; Wang et al. 2000, 2013; Chou et al. 2003; Wu et al. 2003; Yun et al. 2013; Lee et al. 2011a,b, 2014). Wang et al. (2000, 2013) pointed out that El Niño heating over the central and eastern equatorial Pacific leads to an anomalous WNPAC. In addition, the sea surface temperature (SST) anomaly in the Indian Ocean, following the El Niño events, contributes to the persistence of WNPAC 
41 (e.g., Yang et al. 2007; Li et al. 2008; Xie et al. 2009; Ding et al. 2010; Yun et al. 2010;

Chowdary et al. 2010, 2014; Kosaka et al. 2013). Thus, previous studies have focused mainly on the impacts of ENSO-related SST anomalies over the Pacific Ocean and Indian Ocean and less attention has been paid on the Atlantic Ocean.

There is increasing evidence of the remote impact of Atlantic Ocean on the tropical Pacific Ocean and ENSO events (e.g., Rodriguez-Fonseca et al. 2009; Ding et al. 2012; Kucharski et al. 2011; Ham et al. 2013; Hong et al. 2013). Kucharski et al. (2011) showed that the warming over the Atlantic Ocean modulates the mean atmospheric field over the tropical Pacific by inducing an anomalous Walker circulation and leads to a cooling over the eastern tropical Pacific. Ham et al. (2013) suggested that the SST anomaly over the tropical north Atlantic (TNA) could be a trigger for El Niño events by inducing an atmospheric teleconnetion over the tropical Pacific.

Moreover, for the modulation of TNA SST on the WNP summer climate, Hong et al. (2013) pointed out that the TNA warming could induce strong easterly and increased precipitation anomalies over the eastern to central Pacific by using an atmospheric general circulation model (AGCM). They highlighted the role of local moisture feedback over the warm pool region in response to the TNA forcing rather than the detailed mechanism of the teleconnection between TNA SST and WNP summer climate. In addition, Hong et al. (2014) argued an enhancement of relationship between TNA SST and WNP summer climate after the early 1980s. 
However, the detailed mechanisms responsible for this decadal change have not been

63 fully elucidated.

64 The connection between the Atlantic Ocean and Pacific Ocean has been increased

65 since the late 1960s (Polo et al. 2008; Rodriguez-Fonseca et al. 2009). This increased

66 relationship in the late 1960 s seems to concur with a negative phase of the Atlantic

67 multidecadal oscillation (AMO) in observations (Knight et al. 2005), suggesting that

68 AMO might be an important factor that modulates the relationship between Atlantic

69 and Pacific. In addition, as a leading mode of multidecadal SST variability, the AMO

70 has influence not only on the Atlantic region but also on other ocean basins (e.g.,

71 Dong et al. 2006; Sutton and Hodson 2007; Li et al. 2008).

72 The observational records reveal a negative AMO phase during the late 1960s to

73 the 1990s, followed by a positive phase after the late 1990s (Knight et al. 2005). The

74 fluctuation of AMO can arise through the variation of Atlantic thermohaline

75 circulation (THC; e.g., Delworth and Mann 2000; Curry et al. 2003; Zhai and Sheldon

76 2012), although there is also evidence that changes in natural (e.g. volcanic) or

77 anthropogenic (aerosols) external forcing can exert an important influence (e.g.,

78 Ottera et al. 2010; Booth et al. 2012; Zhang et al. 2013). Furthermore, by using

79 coupled models, a substantially weakened THC could produce a negative phase of

80 AMO through a water-hosing experiment in which an extra freshwater flux is

81 artificially applied in the North Atlantic (e.g., Dong and Sutton 2002; Dahl et al. 2005;

82 Zhang and Delworth 2005; Dong and Sutton 2007, Haarsma et al. 2008; Laurian et al. 

2009; Lu and Dong 2008; Lu et al. 2008).

The weakened THC significantly influences both the mean states and interannual variability of SST over the Atlantic (e.g., Polo et al. 2013). The climatological SST changes exhibit as a cooling in the North Atlantic and a warming in the South Atlantic, because of the pronounced decrease of northward ocean heat transport under the weakened THC (e.g., Dong and Sutton 2002; Dahl et al. 2005; Zhang and Delworth 2005; Timmermann et al. 2007). In addition, the interannual variability of SST over the Atlantic Ocean can be modulated by the weakened THC (Haarsma et al. 2008; Polo et al. 2013). Polo et al. (2013) suggested an enhancement of tropical Atlantic variability in boreal late spring-early summer, which is due to an increase in the variance of wintertime ENSO through affecting anomalous surface heat fluxes. Furthermore, the changes in the Atlantic Ocean under the weakened THC could be extended to the Pacific. The SST anomalies over the Atlantic modulate the mean states of wind filed over the tropical Pacific by the atmospheric bridge (e.g., Zhang and Delworth 2005; Timmermann et al. 2007). In addition, this modulation further affects the ENSO variability (Dong and Sutton 2007), the mean states of Asian summer monsoon (Lu and Dong 2008) and the relationship between ENSO and south Asian summer monsoon (Lu et al. 2008).

This study demonstrates how the impacts of TNA SST on the WNP summer climate are strengthened under the background of weakened THC by comparing a water-hosing sensitivity experiment with a control simulation. The model and 
106 the changes of TNA SST variability affecting WNP summer climate by the weakened

107 THC and Section 5 provides the observed evidence. The summary and discussion are 108 given in Section 6.

\section{Model and experiment}

111 Circulation Model (HadCM3; Gordon et al. 2000) is used in this work. The

112 atmospheric component of HadCM3 has 19 levels with a horizontal resolution of $2.5^{\circ}$

113 latitude by $3.75^{\circ}$ longitude (Pope et al. 2000), and the oceanic component has 20

114 levels with a horizontal resolution of $1.25^{\circ}$ by $1.25^{\circ}$. The control simulation (CNTL)

115 uses pre-industrial atmospheric trace gas concentrations and incoming solar radiation

116 providing the only external forcing and maintains a stable climate (Gordon et al. 117 2000).

118 A water-hosing experiment (1Sv hereafter) is performed in which an extra

119 freshwater flux of $1.0 \mathrm{~Sv}\left(1 \mathrm{~Sv}=10^{6} \mathrm{~m}^{3} \mathrm{~s}^{-1}\right)$ is applied uniformly for 100 years to the

120 ocean surface of the North Atlantic between $50^{\circ} \mathrm{N}$ and $70^{\circ} \mathrm{N}$. The external fresh water

121 flux is then switched off after model year 100 and integration continues for an

122 additional 100 years. This experiment is started with the same initial condition with

123 the CNTL (see more details from Dong and Sutton (2007)). The $1.0 \mathrm{~Sv}$ freshwater 
124 flux leads to quickly decrease of THC in the first four decades. After that, a stable

125 strength of THC, with a 70\% weakening in comparison with that in the CNTL, is kept

126 for the last integration years (Dong and Sutton 2007). In this study, we analyze the

127 last 160 years of the $1 \mathrm{~Sv}$ and compare with a parallel CNTL to highlight the impacts

128 of TNA SST anomaly on the WNP summer climate under the weakened THC. The

129 same simulations have been used to investigate the impacts of the weakened THC on

130 the interannual variability of TNA SST (Polo et al. 2013), the ENSO variability (Dong

131 and Sutton 2007), and the Asian summer monsoon climate (Lu and Dong 2008).

132 In addition, the observational datasets used in this study include the Hadley

133 Centre sea ice and sea surface temperature (HadISST; Rayner et al. 2003) with a

134 horizontal resolution of $1^{\circ}$ by $1^{\circ}$ ) for the period of 1948-2012, and lower-tropospheric

135 circulation data from the National Centers for Environmental Prediction

136 (NCEP)/National Center for Atmospheric Research (NCAR) reanalysis data with

137 horizontal resolution of $2.5^{\circ}$ by $2.5^{\circ}$ (Kalnay et al. 1996) within the same period.

138 Boreal summer June, July and August (JJA) is a major target season in this study.

\section{Robust influence of Atlantic SST on the WNP}

Figure 1 exhibits spatial distribution of JJA-mean SST anomalies related to the

141 WNPAC with and without ENSO influence, respectively, during the period of

142 1967-1997 when the AMO was in a negative phase in observations. Here, the strength

143 of WNPAC is defined by averaging $850-\mathrm{hPa}$ stream-function anomalies over the 

to be associated with (1) the negative SST anomaly over the central and eastern

146 tropical Pacific, (2) the positive SST anomaly over the WNP and the North Indian 147 Ocean (NIO), and (3) the positive SST anomaly over the TNA as shown in Fig. 1a. 148 The relative contributions of simultaneous SST anomaly over different ocean regions 149 can be demonstrated by their correlation coefficients with the WNPAC index (Table. 150 1). The WNPAC is mainly correlated with the SST anomaly over the central (Niño 4: 151 SST anomalies averaged over $5^{\circ} \mathrm{S}-5^{\circ} \mathrm{N}, 160^{\circ} \mathrm{E}-150^{\circ} \mathrm{W}$ ) and the eastern (Niño 3: SST 152 anomalies averaged over $5^{\circ} \mathrm{S}-5^{\circ} \mathrm{N}, 90^{\circ}-150^{\circ} \mathrm{W}$ ) tropical Pacific, which can be 153 recognized as strong ENSO signals. The SST over the TNA (averaged over $0^{\circ}-20^{\circ} \mathrm{N}$, $15430^{\circ}-80^{\circ} \mathrm{W}$ ) plays a secondary role in the WNPAC, which is relatively weak, 155 compared with those associated with the ENSO signals. In addition, the SST anomaly 156 over the $\mathrm{NIO}\left(5^{\circ}-20^{\circ} \mathrm{N}, 40^{\circ}-100^{\circ} \mathrm{E}\right)$ and the WNP $\left(5^{\circ}-25^{\circ} \mathrm{N}, 110^{\circ}-160^{\circ} \mathrm{E}\right)$ also 157 contribute to the WNPAC.

It is noted that the contribution of TNA SST to the WNPAC is intensified after 159 removing the ENSO influence. We use the Niño 4 index to represent the ENSO signal, 160 since it not only has the strongest influence on the WNPAC, but also has the closest 161 relationship with both SST anomalies over the eastern tropical Pacific and Indian 162 Ocean (Table. 1). The impacts of Niño 4 SST are first eliminated by using the linear 163 regression for the original SST and circulation field with respect to the Niño 4 index, 164 and then the WNPAC and SST indices, as well as the regression analysis, are 
166 enhanced after the impacts of Nino 4 SST are removed, with a significant correlation

167 coefficient of 0.506 in comparison with 0.344 before. On the contrary, the correlation

168 coefficient of the WNPAC with the Niño 3 index sharply decreased. In addition, the

169 correlation coefficient of WNPAC index with the TNA SST index is also stronger than

170 its correlations with NIO and WNP SST indices, although they have somewhat

171 increased, compared with originals. The results indicate that the WNP summer

172 climate could depends on the SST anomaly over the TNA in addition to the tropical

173 Pacific and Indian Oceans.

174 Figure $1 \mathrm{~b}$ shows the regressions of SST anomalies onto the WNPAC index after

175 excluding the impacts of the Niño 4 index. In comparison with the original SST

176 anomalies shown in Fig. 1a, SST anomalies over the tropical Pacific are considerably

177 weakened since the SST pattern related to ENSO has been removed. Moreover, the

178 SST over the TNA is enhanced, with a normalized SST anomaly increasing from 0.23

179 to 0.33 . This figure indicates that the WNPAC is mainly related to the SST anomaly

180 over the TNA after excluding the impacts of Niño 4 SST. Thus, in the following part,

181 in order to show the robust impact of TNA SST anomaly on the WNP summer climate,

182 the ENSO effect is first removed by using the linear regression with respect to the

183 Niño 4 index.

184 To clearly demonstrate the variation of TNA SST and WNPAC indices and their

185 relationship, Fig. 2 shows the time series of these two indices during the period of 

WNPAC indices. The positive correlation means that a TNA warming (cooling) is associated with anomalous anticyclonic (cyclonic) circulation over the WNP. Furthermore, after removing the impacts of Niño 4 SST, this positive correlation is significantly enhanced, indicating an intensified relationship between TNA SST variability and the WNPAC without ENSO. To illustrate causality, Fig. 3 shows the lead-lag correlation between monthly-mean TNA SST and JJA-mean WNPAC indices, following Svendsen et al.

194 (2013). A significant positive correlation coefficient starts when TNA SST index is 195 leading seven month (Previous December). And the correlation coefficients are 196 stronger when the TNA SST is leading than those when the WNPAC is leading. The 197 results suggest that the TNA SST variability might be a cause for the WNPAC.

198 Moreover, the correlation between TNA SST and WNPAC are significant intensified 199 from spring to summer after eliminating the Niño 4 SST impacts, which further 200 indicates that the modulation of TNA SST on the WNPAC is enhanced without ENSO 201 influence.

202 Figure 4 shows the SST anomalies associated with the WNPAC in the CNTL. 203 The model can reproduce the WNPAC-associated positive SST anomaly over the 204 TNA and Indian Ocean and the negative SST anomaly over the central and eastern 205 tropical Pacific, although the ENSO signal is extended to the western Pacific likely 206 due to the error of cold tongue extending too far westward in the coupled model 
207 (Collins et al. 2001). After excluding the impacts of Niño 4 SST (Fig. 4b), on the one

208 hand, the area with significant positive SST anomaly over the TNA is broadened with

209 an intensified strength (the normalized TNA SST anomaly increases from 0.05 to

210 0.12). On the other hand, the SST anomalies over the tropical Pacific are weakened

211 [normalized Niño 4 (Niño 3) varies from $-0.33(-0.20)$ to $0.01(0.09)]$. Thus, the

212 CNTL not only captures the TNA warming associated with strong WNPAC, but also

213 reproduces the enhanced warming after excluding the impacts of Niño 4 signal,

214 although the model slightly underestimates the strength of positive SST anomaly over 215 the TNA.

\section{4. The impacts of the weakened THC}

\section{$217 \quad 4.1$ Mean and variability of the TNA SST}

The impacts of the weakened THC on the TNA SST are first investigated by

219 comparing the $1 \mathrm{~Sv}$ and CNTL results for 160 years. The difference of climatological

220 mean SST between the 1Sv and CNTL indicates that the SST response in the Atlantic

221 Ocean to the weakened THC is characterized by an interhemispheric asymmetry with

222 a cooling over the northern hemisphere and a warming over the southern hemisphere

223 (Fig. 5a). The North Atlantic SSTs decrease in a range from $1.0^{\circ}$ to $5.0^{\circ} \mathrm{C}$ over the

224 region south of $45^{\circ} \mathrm{N}$. The southern Atlantic warms by about $1.0^{\circ} \mathrm{C}-1.5^{\circ} \mathrm{C}$, because of

225 decreased northward ocean heat transport under the weakened THC (Stouffer et al.

226 2006). This cooling of the North Atlantic and warming of the South Atlantic is 
consistent with previous coupled modeling studies (Dong and Sutton 2002; Dahl et al.

228 2005; Zhang and Delworth 2005) and with the multi-model results of Timmermann et

229 al. (2007). In addition to the local SST response, the weakened THC also induces a

230 cooling (about $1.0^{\circ} \mathrm{C}$ ) in the eastern tropical Pacific, which is associated with a

231 shallow thermocline there (Dong and Sutton 2007).

232 Figures $5 \mathrm{~b}$ shows the differences of SST standard deviation between the two

233 experiments for the original SST field. Under the weakened THC, the interannual

234 variability of North Atlantic shows a significant enhancement. The increase of

235 amplitude for the TNA region is $0.55^{\circ} \mathrm{C}$ (from $0.33^{\circ} \mathrm{C}$ in the CNTL to 0.88 in the $1 \mathrm{~Sv}$ ).

236 In addition, the standard deviation of SST over the tropical eastern Pacific also

237 increases, which indicates the intensification of ENSO variability in the 1Sv (Dong

238 and Sutton 2007). Furthermore, after removing the ENSO impact by using the Niño 4

239 index, the interannual variability of North Atlantic still increases in the 1Sv (Fig. 5c),

240 although the TNA SST is influenced partly by the ENSO variability (Alexander and

241 Scott 2002; Chiang and Sobel 2002). Over the TNA region, the standard deviation is

242 increased by $159 \%$ from $0.32^{\circ} \mathrm{C}$ to $0.83^{\circ} \mathrm{C}$. The enhancement of TNA SST variability

243 without ENSO impacts might be due to the shallow thermocline and increased

244 thermocline feedback over the TNA under the weakened THC, because of the

245 decrease in the thermocline depth over the TNA (not shown). This is consistent with

246 Tokinaga and Xie (2011), who suggested that the local thermocline feedback is

247 another factor to affect the internnual variability over the tropical Atlantic besides 
248 ENSO. The enhancement for interannual variability of the TNA SST under the

249 weakened THC has been argued in Polo et al. (2013). In their study, however, the

250 increase in interannual tropical Atlantic variability is contributed by the intensified

251 ENSO variability. Our study further demonstrates the TNA variability independent

252 from ENSO can also be enhanced under the background of the weakened THC. In

253 short, both the mean states and interannual variability of SST over the TNA are

254 significantly changed under the weakened THC.

$255 \quad 4.2$ Impact on the WNP summer climate

256 This section discusses changes in the response of the WNPAC and WNP climate

257 to the TNA SST variability under the weakened THC by comparing the $1 \mathrm{~Sv}$ and

258 CNTL. ENSO-related variability is removed in all of the analyses. Figure 6 shows

259 the regression patterns of lower-tropospheric stream-function onto the TNA index in

260 the two experiments. In the CNTL, the TNA warming is associated with a pair of

261 cyclonic anomalies located from the eastern Pacific to the western Atlantic and a pair

262 of anticyclonic anomalies that occurred in the western to central Pacific (Fig. 6a).

263 This wave-like pattern indicates a remote connection between the TNA and WNP.

264 Figure $6 \mathrm{~b}$ indicates that the circulation anomalies associated with the TNA warming

265 exhibit a westward shift in the 1Sv. The central area for the cyclonic anomalies moves

266 to the eastern Pacific and that for the anticyclonic anomalies moves to the western

267 Pacific. Particularly, the WNPAC is significantly intensified in the $1 \mathrm{~Sv}$. The strength 
268 of the WNPAC is $0.81 \times 10^{6} \mathrm{~m}^{2} \mathrm{~s}^{-1}$ in the CNTL, but is $1.33 \times 10^{6} \mathrm{~m}^{2} \mathrm{~s}^{-1}$ in the $1 \mathrm{~Sv}$. The 269 enhancement of WNPAC indicates that the impacts of TNA SST on the WNP summer 270 climate are intensified by the weakened THC.

271 Figure 7 shows the pattern of 200 -hPa velocity potential related to the TNA index 272 in the two experiments. The results further indicate a westward shift in the 273 atmospheric response to the TNA warming under the weakened THC. Corresponding 274 with the lower-tropospheric circulation anomaly, the upper troposphere also exhibits a 275 wave-like pattern with a divergence over the eastern Pacific to Atlantic Ocean and a 276 convergence over the western to central Pacific both in the CNTL and 1Sv, indicating 277 the role of large scale tropical divergent circulation for the connection between the 278 TNA SST and the WNP summer climate (e.g., Kucharski et al. 2011, Hong et al. 279 2013). However, this pattern extends westward in the $1 \mathrm{~Sv}$. The central area of 280 convergence shifts westward from the eastern tropical Pacific to the central tropical 281 Pacific, and therefore the strength of convergence over the WNP is intensified. The 282 results suggest that the tropical Atlantic and Pacific could be connected by a Walker 283 circulation anomaly induced by the TNA warming. Moreover, this Walker circulation 284 anomaly is westward extended and results in an intensified relationship between TNA 285 SST and WNP summer climate in the 1Sv, in compared to the CNTL.

286 Figure 8 shows the precipitation and $850-\mathrm{hPa}$ wind anomalies associated with the 287 TNA index. In the CNTL, the TNA warming enhances the local convection activity 288 and leads to a strong positive precipitation anomaly over the TNA and eastern tropical 
289 Pacific. The western boundary of the positive precipitation anomaly is limited east of $290110^{\circ} \mathrm{W}$ (Fig. 8a). The associated diabatic heating gives rise to a pair of 291 lower-tropospheric cyclonic anomalies over its western side (Fig. 6a) as a Gill-pattern 292 Rossby wave response, which generates northeasterly on the western flank (Fig. 8a). 293 This wind anomaly is associated with a negative precipitation anomaly over the 294 central and eastern tropical Pacific through enhancing the wind speed, dry advection 295 (Xie 1999; Ham 2007) and resultant anomalous sinking motion (Fig. 7a). Furthermore, 296 the negative precipitation anomaly induces a pair of anticyclonic anomalies over the 297 western to central Pacific (Fig. 6a), with northerly flow on its eastern edge (Fig. 8a), 298 which further reinforces the negative precipitation anomaly. This strong positive 299 feedback between the precipitation and wind anomaly delivers the influence of the 300 Atlantic on the Pacific. It should be mentioned that Ham et al. (2013) has suggested 301 similar physical processes taking place in spring. Our study further indicates that the 302 connection between TNA SST and WNP climate by the atmospheric teleconnetion 303 also occurs in summer.

304 Figure 8b shows that the changes in precipitation and lower-tropospheric wind 305 anomaly associated with the TNA warming also occur in the $1 \mathrm{~Sv}$. The positive 306 precipitation anomalies in response to the TNA warming extend to the eastern 307 equatorial Pacific, with the west edge around $120^{\circ} \mathrm{W}$ (Fig. 8b). The corresponding 308 cyclonic anomaly extends to the eastern Pacific (Fig. 6b), which leads to the 309 anomalous sinking motion moving to the central tropical Pacific (Fig. 7b) and the 
negative precipitation anomaly shifting westward to the central to western tropical

311 Pacific (Fig. 8b). As a result, the anticylonic anomaly over the WNP, as well as the

312 local negative precipitation anomaly, is intensified (Fig. 8b).

313 The TNA SST anomaly and the WNP summer climate are linked by a coupled

314 interaction between convection and circulation. It can be explained as follows: the

315 TNA warming induces a pair of cyclonic circulation anomaly over the eastern Pacific

316 and negative precipitation anomaly over the eastern to central tropical Pacific, which

317 in turn leads to an anticyclonic circulation anomaly over the western to central north

318 Pacific. These processes occur both in CNTL and 1Sv, acting as a bridge to relay the

319 impacts of Atlantic to the WNP. However, in the 1Sv, the coupled interaction is

320 shifted westward and tends to enhance the WNPAC.

321 Figure 9 shows the SST anomalies related to the TNA warming, which could

322 explain the westward shift of teleconnection pattern associated with the TNA SST

323 change. Because the ENSO signal has been eliminated first, the strong SST anomaly

324 is mainly confined over the North Atlantic in the CNTL (Fig. 9a). In addition, the

325 cooling over the subtropical eastern Pacific is associated with the strong negative

326 precipitation there (Fig. 8a). In the $1 \mathrm{~Sv}$, however, associated with the TNA warming is

327 positive SST anomalies over the eastern tropical Pacific (Fig. 9b). These positive SST

328 anomalies are the response to the westward shift of coupled interaction over the

329 Pacific. The warming in the eastern tropical Pacific is caused by the westerly flow

330 over the equatorial eastern Pacific (Fig. 8b) through decreasing the easterly trades and 
331 suppressing the local upwelling. Even though this westerly flow also exists in the

332 CNTL, the thermocline over the equatorial eastern Pacific is shallower under the

333 weakened THC as illustrated in (Fig. 10. It can been seen that the thermocline depth

334 over the eastern equatorial Pacific is significantly decreased in the $1 \mathrm{~Sv}$ with the

335 difference of $\mathrm{D} 20$ over the region $5^{\circ} \mathrm{S}-5^{\circ} \mathrm{N}, 60^{\circ}-95^{\circ} \mathrm{E}$ of $-16.37 \mathrm{~m}$. The change of

336 thermocline depth over the tropical Pacific under the weakened THC is contributed to

337 by the anomalous Ekman pumping, associated with the anomalous wind stress

338 (Dong and Sutton 2007). Over the eastern tropical Pacific, the shallow thermocline in

339 the $1 \mathrm{~Sv}$ is due to the increased Ekman upwelling induced by the local easterly wind

340 stress. The shallower thermocline over the equatorial eastern Pacific increases the

341 sensitivity of SST variability to local wind change. Therefore, the change of

342 thermocline depth over the eastern Pacific under the weakened THC plays a crucial

343 role in the enhancement of the impacts of TNA SST on the WNP summer climate by

344 westward shift of coupled interactions among SST, convection and circulation over

345 the tropical Pacific.

\section{5. Observational evidence}

347 Our finding of intensification in the impacts of the TNA SST on the WNPAC

348 under the weakened THC is further confirmed by observational evidence. Here a

349 positive AMO is combined by two periods of 1948-1966 and 1998-2012 (total of 34

350 years), comparing with a negative AMO represented by the period of 1967-1997 (31 
351 years). The linkage between the TNA SST and WNPAC in the positive phase of AMO

352 is weaker than that in the negative phase of AMO in observations. The correlation

353 coefficient between the TNA SST and WNPAC without ENSO influence is only 0.265

354 during the positive AMO, in contrast to a significant one of 0.506 in the negative

355 AMO. The results indicate that the negative phase of AMO, most likely related to a

356 weakened THC, is more in favour for a strong teleconnection between the TNA SST

357 and WNP summer climate than the positive AMO.

358 Figure 11 shows the circulation response to the TNA warming during the

359 negative and positive AMO phases, respectively. The enhancement in the connection

360 between the TNA SST and the WNPAC is further indicated by the strong circulation

361 anomalies over the WNP during the negative AMO than those during the positive one.

362 In the lower troposphere, the TNA warming induces a cyclonic anomaly over the

363 eastern tropical Pacific and an anticyclonic anomaly over the WNP in both negative

364 and positive AMO (Figs. 11a and c). However, the WNPAC shown in Fig. 11a is

365 strong and well organized, indicating a strong response of the WNP summer climate

366 to the TNA SST during the negative AMO, similar to those in the 1 Sv (Fig. 6b). In the

367 period of the positive AMO, however, the circulation anomaly associated with the

368 TNA warming is much weaker (Fig. 11b). The weakened WNPAC implies a decrease

369 in the teleconnection between TNA and WNP during the positive AMO. The stronger

370 circulation response to the TNA warming in the negative AMO than that in the

371 positive AMO also shows in the upper troposphere. The convergence over the tropical 
372 Pacific is strong and extends to the WNP in the negative AMO (Fig. 11c), in

373 comparison with a weakened one in the positive AMO (Fig. 11d). Thus, the strong

374 linkage between the TNA SST and WNP summer climate in the negative AMO during

375 the late 1960s-1990s further confirms that the weakened THC (a negative AMO)

376 provides a favorable background for the enhancement of the teleconnection between

377 TNA SST and the WNPAC.

378 6. Summary and discussion

379 By using two experiments (CNTL and 1Sv) with the HadCM3, this study

380 demonstrates that the impacts of the TNA warming on the WNP summer climate tend

381 to be intensified under the background of the weakened THC (the negative AMO

382 phase in other word). Observational analysis also confirms modeling results.

383 The WNP summer climate is mainly regulated by the SST anomaly over the

384 tropical Pacific, the Indian Ocean and the TNA in observations. However, the SST

385 variabilities over the Indian Ocean and tropical Pacific are closely correlated with

386 each other, as well as with TNA SST variability. After excluding the ENSO influence,

387 the relationship between the TNA SST and WNPAC is greatly intensified,

388 highlighting the influence of the TNA SST on the WNP summer climate.The TNA

389 warming is associated with anomalous WNPAC during summer. The physical

390 processes connecting the TNA and the WNP are illustrated by the CNTL. On the one

391 hand, the TNA warming is associated with anomalous divergence from the eastern 
392 Pacific to Atlantic Ocean and anomalous convergence from the western to central

393 Pacific in the upper troposphere, indicating the role of large scale tropical divergent

394 circulation for the connection between the TNA SST and the WNP summer climate.

395 On the other hand, the positive SST anomaly over the TNA enhances the local 396 convection which gives rise to a cyclonic anomaly over the eastern Pacific by 397 inducing anomalous diabatic heating. The northeasterly flow on the western edge of 398 the cyclonic anomaly contributes to a negative precipitation over the eastern to central 399 tropical Pacific, which in turn generates the anticyclonic anomaly over the western to 400 central tropical Pacific. Moreover, the circulation and precipitation anomalies over 401 the tropical Pacific have a positive feedback to intensify each other. Therefore, the 402 coupled convection-circulation interaction over the Pacific associated with the TNA 403 SST anomaly delivers the impacts of TNA SST to the WNP.

404 The impacts of TNA SST on the WNP summer climate are intensified under the 405 weakened THC. In the 1Sv, the WNPAC and associated precipitation anomaly 406 response to the TNA warming are enhanced. This enhancement is due to the westward 407 shift of the teleconnection pattern related to the TNA SST. Under the weakened THC, 408 the thermocline over the eastern equatorial Pacific is shallower than that in the CNTL. 409 The shallow thermocline increases the sensitivity of SST to surface wind anomalies in 410 the eastern tropical Pacific. Meanwhile, the circulation and precipitation anomalies 411 associated with TNA warming are shifted westward. Especially, the anticyclonic 412 anomaly moves to the western Pacific, which leads to an enhanced WNPAC and 
413 strong negative precipitation anomaly there. This result indicates the role of changes

414 in mean states over the equatorial eastern Pacific by the weakened THC in increasing

415 the influence of TNA SST on the WNP summer climate.

416 It should be noted that the physical processes is obtained through the positive

417 TNA SST anomaly by linear regression analysis, but it also makes physical sense for

418 the negative TNA SST anomaly. The composite analysis of negative TNA SST

419 anomaly (not shown) suggested that the TNA cooling leads to a cyclonic circulation

420 anomaly over the western to central north Pacific in the CNTL. Moreover, under the

421 weakened THC, the TNA cooling extends to the eastern tropical Pacific, and the

422 atmospheric response to the TNA cooling are westward shifted and therefore

423 enhances the cyclonic circulation and positive precipitation anomaly over the WNP.

424 Thus, TNA cooling also have stronger impacts in the 1Sv than those in the CNTL.

425 In addition, considering theNiño 3 SST variability is strongest in DJF over the

426 tropical Pacific, the circulation response to the TNA after removing the impacts of

427 DJF-mean Niño 3 variability is also investigated. The results indicate the WNPAC is

428 intensified in the $1 \mathrm{~Sv}$ without the impacts of SST over the eastern tropical Pacific.

429 These indicate that the main conclusions are robust and they are not sensitive to how

430 the ENSO impacts are removed.The intensification in the impacts of TNA SST on the

431 WNPAC under the weakened THC is further confirmed by the stronger connection

432 between the TNA SST and the WNPAC in a negative phase of AMO than that in a

433 positive one in observations. During the late 1960s-1990s characterized as a negative 
434 AMO, the TNA SST is closely related to the WNP by inducing a strong WNPAC.

435 However, it should be mentioned that in observations, the circulation anomalies

436 associated with TNA warming do not exhibit a clear westward shift during the

437 negative phase of AMO, unlike the simulations, possibly due to the smaller sampling

438 size in observations and weaker SST anomalies associated with AMO compared with

439 those associated with substantial weakened THC.

440 The results presented in this study indicate the importance of the Atlantic SST

441 anomaly in modulating the WNP summer climate via a tropical teleconnection.

442 Furthermore, the changes in mean states on decadal timescale can modulate this

443 impact. Thus, more attention should be paid on the Atlantic SST for improving the

444 seasonal prediction of WNP summer climate.

445

446 Acknowledgements

447 This study was supported by the National Natural Science Foundation of China

448 (Grant Nos. 41105046 and 41320104007$).$

449 
Alexander MA, Scott JD (2002) The influence of ENSO on air-sea interaction in the Atlantic. Geophys Res Lett 29:1701. doi:10.1029/2001GL014347

Booth BB, Dunstone NJ, Halloran PR, Andrews T, Bellouin N (2012) Aerosols implicated as a prime driver of twentieth-century North Atlantic climate variability. Nature 484:228-233

Chang CP, Zhang YS, Li T (2000) Interannual and interdecadal variations of the East Asian summer monsoon and tropical Pacific SSTs. Part I: Roles of the subtropical ridge. J Clim 13:4310-4325

Chiang JCH, Sobel AH (2002) Tropical tropospheric temperature variations caused by ENSO and their influence on the remote tropical climate. J Clim 15:2616-2631

461 Chou C, Tu JY, Yu JY (2003) Interannual variability of the western North Pacific $16: 2275-2287$

464 Chowdary JS, Xie SP, Lee JY, Kosaka Y, Wang B (2010) Predictability of summer forcing. J Geophys Res 115: D22121

467 Chowdary JS, Attada R, Lee JY, Kosaka Y et al (2014) Seasonal prediction of distinct 468 climate anomalies in the summer 2010 over the tropical Indian Ocean and South Asia. J Meteorol Soc Jpn 92: 1-16 
470 Collins M, Tett SFB, Cooper C (2001) The internal climate variability of HadCM3, a 471 version of the Hadley Centre coupled model without flux adjustments. Clim Dyn $472 \quad 17: 61-81$

473 Curry R, Dickson B, Yashayaev I (2003) A change in the freshwater balance over the 474 Atlantic Ocean over the past four decades. Nature 426:826-829

475 Dahl KA, Broccoli AJ, Stouffer RJ (2005) Assessing the role of North Atlantic 476 freshwater forcing in millennial scale climate variability: a tropical Atlantic 477 478 479 480 481 482 perspective. Clim Dyn 24:325-346. doi:10.1007/s00382-004-0499-5

Delworth TL, Mann ME (2000) Observed and simulated multidecadal variability in the Northern Hemisphere. Clim Dyn 16:661-676. doi:10.1007/s003820000075

Ding H, Keenlyside NS, Latif M (2012) Impact of the equatorial Atlantic on the El Niño Southern oscillation. Clim Dyn 38:1965-1972. doi:10.1007/s00382-011-1097-y

Ding R, Ha KJ, Li J (2010) Interdecadal shift in the relationship between the East Asian summer monsoon and the tropical Indian Ocean. Clim Dyn 34:1059-1071. doi:10.1007/s00382-009-0555-2

Dong B, Sutton RT (2002) Adjustment of the coupled oceanatmosphere system to a sudden change in the thermocline circulation. Geophys Res Lett 29:1728. doi:10.1029/2002GL015229

Dong B, Sutton RT (2007) Enhancement of ENSO variability by a weakened Atlantic 490 thermocline circulation in a coupled GCM. J Clim 20:4920-4939 
491 Dong B, Sutton RT, Scaife AA (2006) Multidecadal modulation of El Niño-Southern 492 Oscillation (ENSO) variance by Atlantic Ocean sea surface temperatures. 493 Geophys Res Lett 33:L08705. doi:10.1029/2006GL025766

494 Gordon C, Cooper C, Senior CA, Banks H, Gregory JM, Johns TC, Mitchell JFB, 495 Wood RA (2000) The simulation of SST, sea ice extents and ocean heat transports 496 in a version of the Hadley Centre coupled model without flux adjustments. Clim Dyn 16:147-168.

Haarsma RJ, Campos E, Hazeleger W, Severijns C (2008) Influence of the meridional overturning circulation on tropical Atlantic climate and variability. J Clim

501 Ham YG, Kug JS, Kang IS (2007) Role of moist energy advection in formulating 502 anomalous Walker Circulation associated with ENSO. J Geophy Res 112:D24105. doi:10.1029/2007JD008744

Ham YG, Kug JS, Park JY, Jin FF (2013) Sea surface temperature in the north tropical Atlantic as a trigger for El Niño/Southern Oscillation events. Nat Geosci 6(2):112-116. doi:10.1038/ngeo1686

507 Hong CC, Chang TC, Hsu HH (2014) Enhanced relationship between the tropical the early 1980s. J Geophys Res doi:10.1002/2013JD021394

Hong S, Kang IS, Choi I, Ham YG (2013) Climate responses in the tropical Pacific associated with Atlantic warming in recent decades. Asia-Pac J Atmos Sci 
513 Kalnay E, Kanamitsu M, Kistler R et al (1996) The NCEP/NCAR 40-Year Reanalysis $514 \quad$ Project. Bull. Amer Meteor Soc, 77:437-471

515 Knight JR, Allan RJ, Folland CK, Vellinga M, Mann ME (2005) A signature of 516 persistent natural thermohaline circulation cycles in observed climate. Geophys Res Lett 32:L20708. doi:10.1029/2005GL024233

518 Kang IS, Lee JY, Park CK (2004) Potential predictability of summer mean correction. J Clim 17: 834-844

521 Kosaka Y, Chowdary JS, Xie SP, Min YM, Lee JY (2012) Limitations of seasonal predictability for summer climate over East Asia and the Northwestern Pacific. J Clim 25: 7574-7589

KosakaY, Xie SP, Lau NC, Vecchi GA (2013) Origin of seasonal predictability for 525 summer climate over the Northwestern Pacific. PNAS 110: 7574-7579

526 Kucharski F, Kang IS, Farneti R, Feudale L (2011) Tropical Pacific response to 20th century Atlantic Warming. Geophys Res Lett 38:L03702, doi:10.1029/2010GL046248

529 Laurian A, Drijfhout SS, Hazeleger W, van Dorland R (2009) Global surface cooling: 530 the atmospheric fast feedback response to a collapse of the thermohaline circulation. Geophys Res Lett 36:L20708. doi:10.1029/2009GL040938

532 Lee JY, Wang B, Seo KH, Kug JS, Choi YS, Kosaka Y, Ha KJ (2014) Future change 

models. J Clim in press. Doi:10.1175/JCLI-D-13-00261.1 multivariate indices for the boreal summer intraseasonal oscillation over the Asian summer monsoon region. Clim Dyn, 40: 493-509

Lee JY, Wang B, Ding Q, Ha KJ, Ahn JB, Kumar A, Stern B, Alves O (2011a) How predictable is the Northern Hemisphere summer upper-tropospheric circulation? Clim Dyn 37: 1189-1203.

541 Lee JY, Wang B, Kang IS, Shukla J et al (2010) How are seasonal prediction skills 542 related to models' performance on mean state and annual cycle? Clim Dyn $35: 267-283$

544 Lee SS, Lee JY, Ha KJ, Wang B, Schemm JKE (2011b) Deficiencies and possibilities for long-lead coupled climate prediction of the western North Pacific-East Asian

Li S, Lu J, Huang G, Hu K (2008) Tropical Indian Ocean basin warming and East summer monsoon. Clim Dyn 36: 1173-1188 Asian summer monsoon: A multiple AGCM study. J Clim 21:6080-6088

Li S, Perlwitz J, Quan X, Hoerling MP (2008) Modelling the influence of North Atlantic multidecadal warmth on the Indian summer rainfall. Geophys Res Lett 35:L05804. doi:10.1029/2007GL032901

Li Y, Lu R, Dong B (2007) The ENSO-Asian monsoon interaction in a coupled ocean-atmosphere GCM. J Clim 20:5164-5177 
554 Lu R, Dong B (2008) Response of the Asian summer monsoon to a weakening of 555 Atlantic thermohaline circulation. Adv in Atmos Sci 25:723-736

556 Lu R, Chen W, Dong B (2008) How does a weakened Atlantic thermohaline 557 circulation lead to an intensification of the ENSO-South Asian summer monsoon 558 interaction? Geophys Res Lett 35:L08706. doi: 10.1029/2008GL033394

559 Moon, JY, Wang B, Ha KJ, Lee JY (2013) Teleconnections associated with Northern 560 Hemisphere summer monsoon intraseasonal oscillation. Clim Dyn, 561 $40: 2761-2774$

562 Ottera OH, Bentsen M, Drange H, Suo L (2010) External forcing as a metronome for 563 Atlantic multidecadal variability. Nature Geosci 3:688-694. doi:10.1038/ NGE0955

565 Polo I, Dong B, Sutton RT (2013) Changes in tropical Atlantic interannual variability 566 from a substantial weakening of the meridional overturning circulation. Clim Dyn 567

Polo I, Rodriguez-Fonseca B, Losada T, Garcia-Serrano J (2008) Tropical Atlantic variability modes (1979-2002). Part I: timeevolving SST modes related to West African rainfall. J Clim 21:6457-6475. doi:10.1175/2008JCLI2607.1

571 Pope VD, Gallani ML, Rowntree PR, Stratton RA (2000) The impact of new physical parameterizations in the Hadley Centre climate model: HadAM3. Clim Dyn 16: 123-146

574 Rayner NA, Parker DE, Horton EB, Folland CK, Alexander LV, Rowell DP, Kent EC, 

since the late nineteenth century. J Geophys Res 108(D14):4407. doi:10.1029/2002JD002670

578

Rodriguez-Fonseca B, Polo I, Garcia-Serrano J, Losada T, Mohino E, Mechoso CR, Kucharski F (2009) Are Atlantic Niños enhancing Pacific ENSO events in recent decades? Geophys Res Lett 36:L20705. doi:10.1029/2009GL040048

Sohn SJ, Min YM, Lee JY et al. (2012) Assessment of the long-lead probabilistic prediction for the Asian summer monsoon precipitation (1983-2011) based on the APCC multimodel system and a statistical model. J Geophy Res 117: D04102, doi:10.1029/2011JD016308

Sutton RT, Hodson DLR (2007) Climate response to basin-scale warming and cooling of the North Atlantic Ocean. J Clim 20:891-907

Svendsen, L., Kvamstø, N.G. and N. Keenlyside (2013) Weakening AMOC connects Equatorial Atlantic and Pacific interannual variability, Clim Dyn doi $10.1007 / \mathrm{s} 00382-013-1904-8$

Timmermann A, Okumura Y, An S-I, Clement A, Dong B, Guilyardi E, Hu A, Jungclaus J, Krebs U, Renold M, Stocker TF, Stouffer RJ, Sutton R, Xie S-P, Yin J (2007) The influence of a weakening of the Atlantic meridional overturning circulation on ENSO. J Clim 20:4899-4919

Tokinaga H, Xie SP (2011) Weakening of the equatorial Atlantic coldtongue over the past six decades. Nat Geosci. doi:10.1038/NGEO1078 
Wang B, Wu RG, Fu XH (2000) Pacific-East Asian teleconnection: How does ENSO affect East Asian climate? J Clim 13: 1517-1536

Wang B, Kang IS, Lee JY (2004) Ensemble simulations of Asian-Australian monsoon variability by 11 AGCMs. J Clim 17, 803-818

600

601

Wang B, Xiang B, Lee JY (2013) Subtropical high predictability establishes a promising way for monsoon and tropical storm predictions. PNAS

602 110:2718-2722

603

Wang B, Lee JY, Xiang B (2014) Asian summer monsoon rainfall predictability: A

604 predictable mode analysis. Clim Dyn accepted

605

Wu RG, Hu ZZ, Kirtman BP (2003) Evolution of ENSO related rainfall anomalies in 606 East Asia. J Clim 16: 3742-3758

607 Xie SP (1999) A dynamic ocean-atmosphere model of the tropical Atlantic decadal 608 variability. J Clim 12:64-70

609 Xie SP, Hu K, Hafner J, Tokinaga H, Du Y, Huang G, Sampe T (2009) Indian Ocean 610 capacitor effect on Indo-Western Pacific climate during the summer following El $611 \quad$ Niño. J Clim 22:730-747

612 Yang J, Liu Q, Xie SP, Liu Z, Wu L (2007) Impact of the Indian Ocean SST basin 613 mode on the Asian summer monsoon. Geophys Res Lett 34:L02708. 614 doi:10.1029/2006GL028571

615 Yu K, Xie SP, Lau NC, Vecchi GA (2013) Origin of seasonal predictability for 616 summer climate over the Northwestern Pacific. PNAS 110:7574-7579 
617 Yun, KS., Ha KJ, Wang B (2010) Impacts of tropical ocean warming on East Asian 618 summer climate. Geophys Res Lett 37:L20809

619 Yun, KS, Yeh SW, Ha KJ (2013) Distinct impact of tropical SSTs on summer North 620 Pacific high and western North Pacific subtropical high. J Geophys Res $621 \quad 118: 4107-4116$

622 Zhai X, Sheldon L (2012) On the North Atlantic ocean heat content change between 623 1955-1970 and 1980-1995. J Clim 25:3619-3628. doi:10.1175/JCLI-D-11-00187.1

625 Zhang R, Delworth TL (2005) Simulated tropical response to a substantial weakening 626 of the Atlantic thermohaline circulation. J Clim 18:1853-1860

627 Zhang R, Delworth TL et al (2013) Have Aerosols Caused the Observed Atlantic 628 Multidecadal Variability? J Atmos Sci 70:1135-1144. doi: $629 \quad$ http://dx.doi.org/10.1175/JAS-D-12-0331.1

630 


\section{Captions}

633 Table 1. Correlation coefficients among the indices in observations. The tropical

634 North Atlantic (TNA), Niño 4, Niño 3, North Indian Ocean (NIO), western North 635 Pacific (WNP) and the western North Pacific anticyclonic anomaly (WNPAC) indices 636 are defined as the anomalies averaged over the region $\left(0^{\circ}-20^{\circ} \mathrm{N}, 30^{\circ}-80^{\circ} \mathrm{W}\right)$, $637\left(5^{\circ} \mathrm{S}-5^{\circ} \mathrm{N}, 160^{\circ} \mathrm{E}-150^{\circ} \mathrm{W}\right),\left(5^{\circ} \mathrm{S}-5^{\circ} \mathrm{N}, 90^{\circ}-150^{\circ} \mathrm{W}\right),\left(5^{\circ}-20^{\circ} \mathrm{N}, 40^{\circ}-100^{\circ} \mathrm{E}\right),\left(5^{-}-25^{\circ} \mathrm{N}\right.$, $\left.638110^{\circ}-160^{\circ} \mathrm{E}\right)$ and $\left(0^{\circ}-25^{\circ} \mathrm{N}, 110^{\circ}-145^{\circ} \mathrm{E}\right)$, respectively. The bold ones represent that 639 the partial correlation coefficients by removing the impacts of Niño 4 index. One or 640 two asterisks represent the correlation coefficients are significant at $95 \%$ or $99 \%$ 641 confidence levels, respectively.

642 Fig. 1. Regression of normalized boreal summer months (JJA)-mean SST anomalies 643 onto the WNPAC index in observations. (a) Original SST anomalies. (b) SST 644 anomalies after removing the impact of Niño 4 SST. The regions within the black 645 lines indicate where the anomalies are significant at $95 \%$ confidence level by F-test. 646 The dashed rectangles represent the regions to define the indices.

647 Fig. 2. Time series for the TNA $\left({ }^{\circ} \mathrm{C}\right)$ and WNPAC $\left(10^{6} \mathrm{~m}^{2} \mathrm{~s}^{-1}\right)$ indices for original data 648 (a) and after eliminating the Niño 4 SST (b) from 1967 to 1997 in observations.

649 Fig. 3. Lead-lag correlation coefficients between monthly-mean TNA and JJA-mean 650 WNPAC indices from 1967 to 1997 in observations. Zero month (-1 month) means 
651 July (June) and left-hand (right-hand) side indicate TNA (WNPAC) leading. Black 652 and red lines represent the lead-lag correlation by original data and after eliminating 653 Niño 4 SST impact, respectively. The dark dashed line represents the $95 \%$ confidence 654 level by t-test.

655 Fig. 4. Same as Fig. 1, but for the 160 years simulation of the CNTL.

656 Fig. 5. Differences of climatological mean SST $\left({ }^{\circ} \mathrm{C}\right.$; a), interannual standard deviation 657 of SST anomalies $\left({ }^{\circ} \mathrm{C} ; \mathrm{b}\right)$ and interannual standard deviation of SST anomalies after 658 removing the Niño 4 index $\left({ }^{\circ} \mathrm{C} ; \mathrm{c}\right)$ in JJA between the $1 \mathrm{~Sv}$ and the CNTL. The regions 659 within the black lines indicate where the differences are significant at $95 \%$ confidence 660 level by $t$-test.

661 Fig. 6. Regression of $850-\mathrm{hPa}$ stream function anomalies $\left(10^{6} \mathrm{~m}^{2} \mathrm{~s}^{-1}\right)$ onto the TNA 662 index in the CNTL (a) and the 1Sv (b).

663 Fig. 7. Same as Fig. 6, but for the 200-hPa velocity potential anomalies $\left(10^{6} \mathrm{~m}^{2} \mathrm{~s}^{-1}\right)$.

664 Fig. 8. Same as Fig. 6, but for the precipitation anomalies $\left(\mathrm{mm} \mathrm{day}^{-1}\right)$ and $850-\mathrm{hPa}$ 665 wind anomalies. For $850-\mathrm{hPa}$ wind, only the anomalies are significant at $95 \%$ 666 confidence level by F-test are shown.

667 Fig. 9. Same as Fig. 6, but for the SST anomalies $\left({ }^{\circ} \mathrm{C}\right)$.

668 Fig. 10. Differences of climatological mean depth of $20^{\circ} \mathrm{C}$ thermocline $(\mathrm{D} 20 ; \mathrm{m})$ in 669 JJA between the $1 \mathrm{~Sv}$ and the CNTL. The regions within the black lines indicate where 670 the differences are significant at $95 \%$ confidence level by $t$-test. The dashed rectangle 671 represents the region to calculate the difference of D20. 
672 Fig. 11. Same as Fig. 6, but for the 850 -hPa stream-function anomalies $\left(10^{6} \mathrm{~m}^{2} \mathrm{~s}^{-1}\right.$; left 673 panel) and $200-\mathrm{hPa}$ velocity potential anomalies $\left(10^{6} \mathrm{~m}^{2} \mathrm{~s}^{-1}\right.$; right panel $)$ during the 674 negate phase of AMO (a, c) and the positive phase of AMO (b, d) in observations. 
Table 1. Correlation coefficients among the indices in observations. The tropical North Atlantic (TNA), Niño 4, Niño 3, North Indian Ocean (NIO), western North Pacific (WNP) and the western North Pacific anticyclonic anomaly (WNPAC) indices are defined as the anomalies averaged over the region $\left(0^{\circ}-20^{\circ} \mathrm{N}, 30^{\circ}-80^{\circ} \mathrm{W}\right)$, $\left(5^{\circ} \mathrm{S}-5^{\circ} \mathrm{N}, 160^{\circ} \mathrm{E}-150^{\circ} \mathrm{W}\right),\left(5^{\circ} \mathrm{S}-5^{\circ} \mathrm{N}, 90^{\circ}-150^{\circ} \mathrm{W}\right),\left(5^{\circ}-20^{\circ} \mathrm{N}, 40^{\circ}-100^{\circ} \mathrm{E}\right),\left(5^{-}-25^{\circ} \mathrm{N}\right.$, $\left.110^{\circ}-160^{\circ} \mathrm{E}\right)$ and $\left(0^{\circ}-25^{\circ} \mathrm{N}, 110^{\circ}-145^{\circ} \mathrm{E}\right)$, respectively. The bold ones represent that the partial correlation coefficients by removing the impacts of Niño 4 index. One or two asterisks represent the correlation coefficients are significant at $95 \%$ or $99 \%$ confidence levels, respectively.

\begin{tabular}{lccccc}
\hline & TNA & Niño 4 & Niño 3 & NIO & WNP \\
\hline WNPAC & 0.344 & $-0.375^{*}$ & $-0.374^{*}$ & 0.194 & 0.316 \\
Niño 4 & 0.281 & 1.000 & $0.657^{* *}$ & $0.417^{*}$ & 0.131 \\
WNPAC & & & & & \\
(-Niño 4) & $\mathbf{0 . 5 0 6 * *}$ & $/$ & $\mathbf{- 0 . 1 8 3}$ & $\mathbf{0 . 4 1 5 *}$ & $\mathbf{0 . 3 9 8 *}$ \\
\hline
\end{tabular}




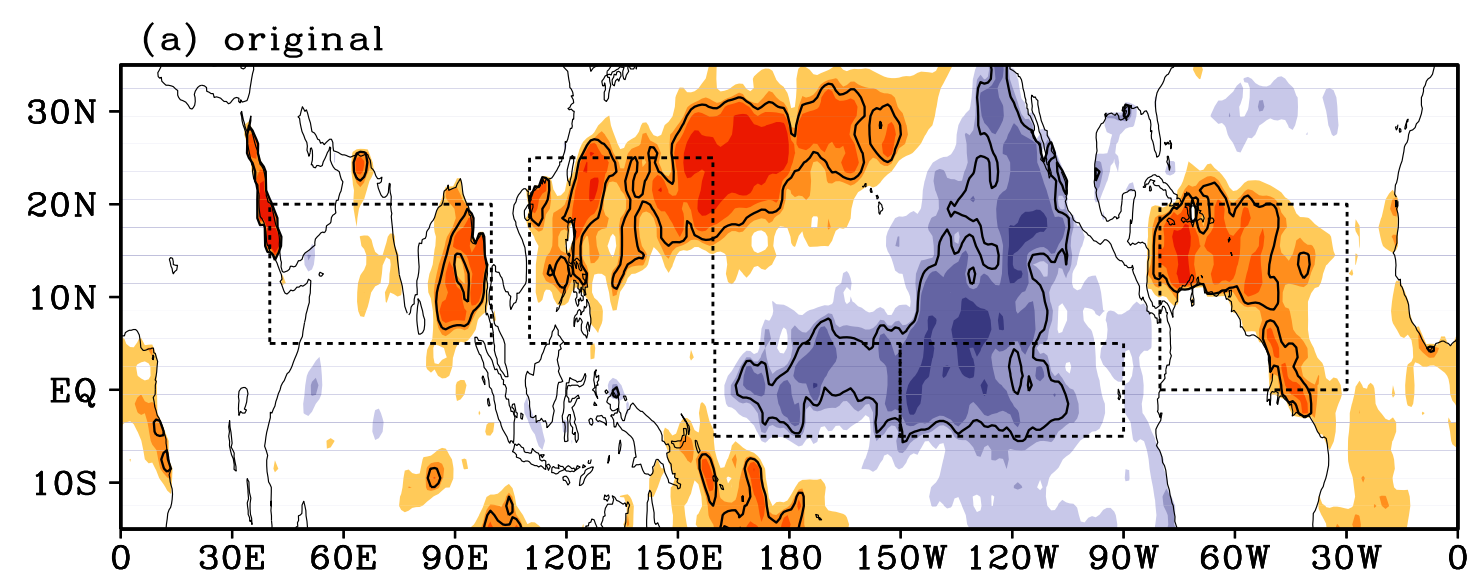

(b) remove Nino4

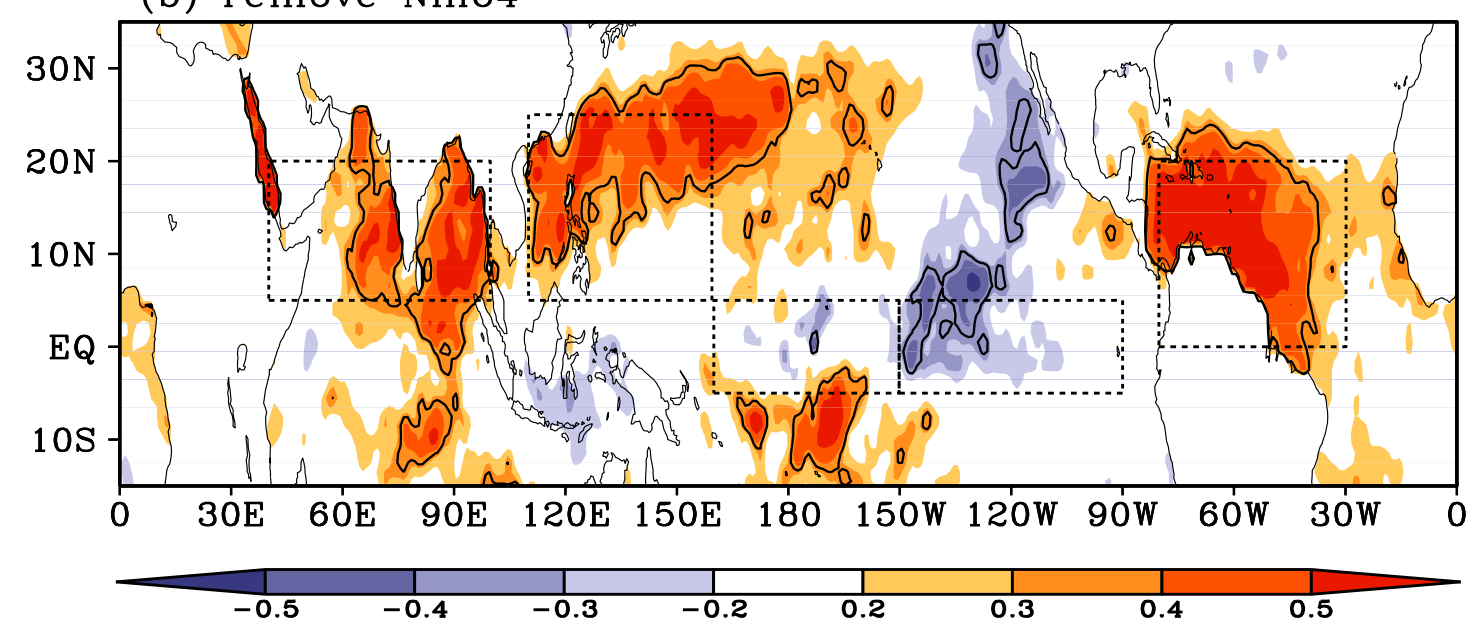

Fig. 1. Regression of normalized boreal summer months (JJA)-mean SST anomalies onto the WNPAC index in observations. (a) Original SST anomalies. (b) SST anomalies after removing the impact of Niño 4 SST. The regions within the black lines indicate where the anomalies are significant at $95 \%$ confidence level by F-test. The dashed rectangles represent the regions to define the indices. 

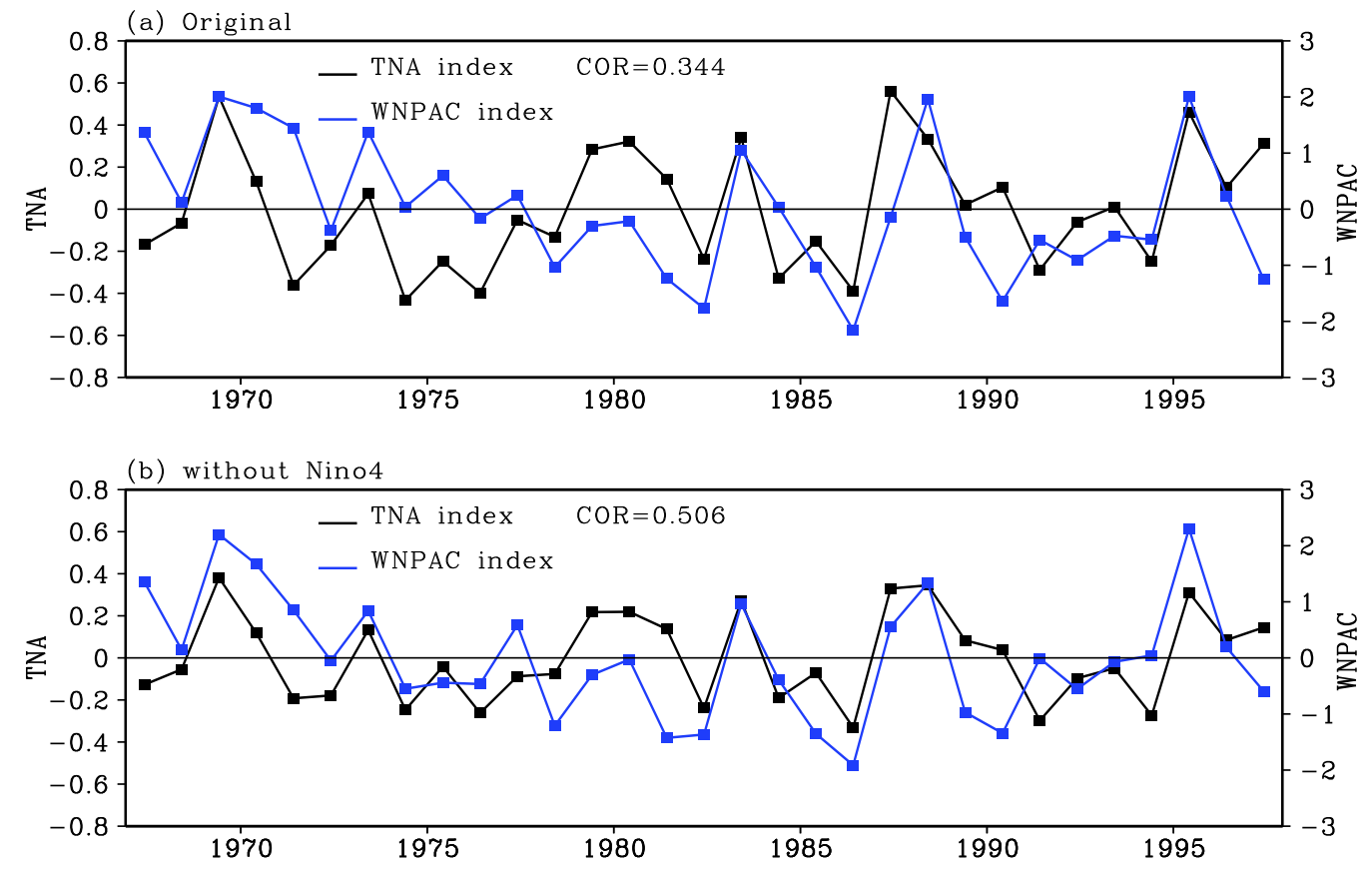

Fig. 2. Times series for the TNA $\left({ }^{\circ} \mathrm{C}\right)$ and WNPAC $\left(10^{6} \mathrm{~m}^{2} \mathrm{~s}^{-1}\right)$ indices for original data (a) and after eliminating the Niño 4 SST (b) from 1967 to 1997 in observations. 


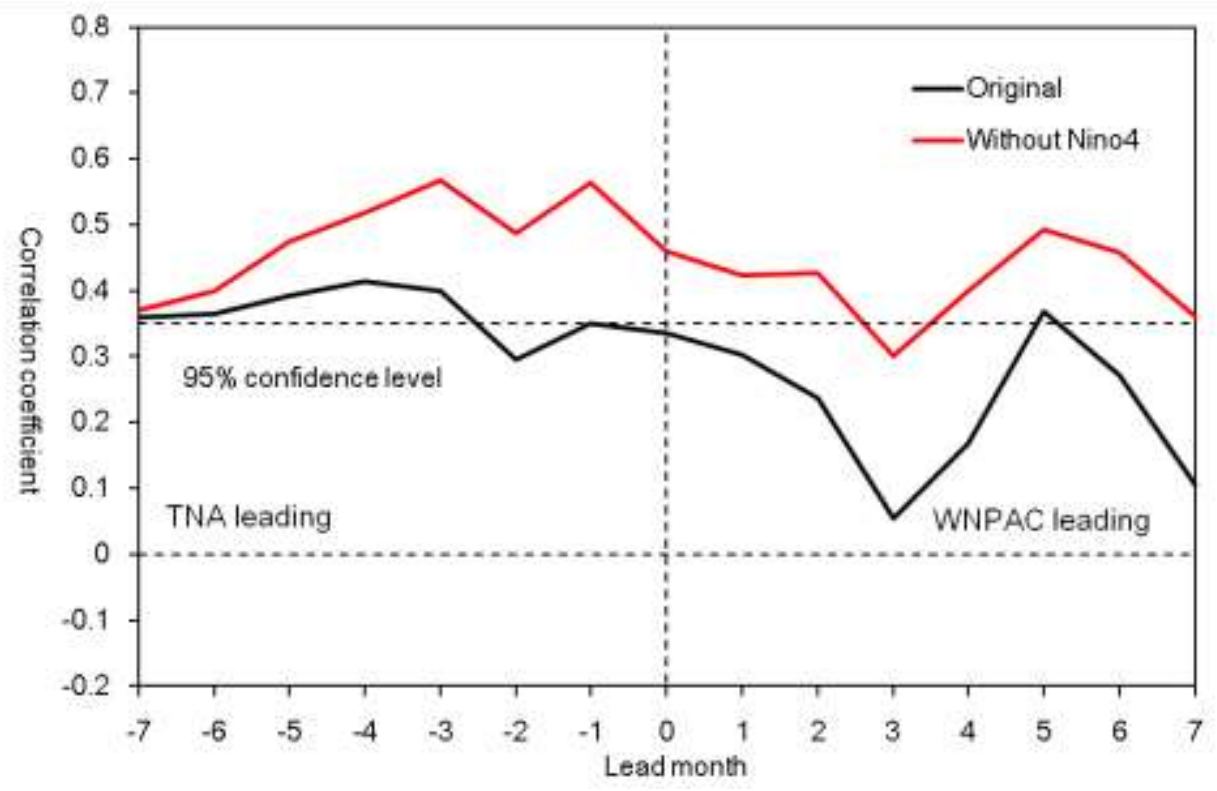

Fig. 3. Lead-lag correlation coefficients between monthly-mean TNA and JJA-mean WNPAC indices from 1967 to 1997 in observations. Zero month (-1 month) means July (June) and left-hand (right-hand) side indicate TNA (WNPAC) leading. Black and red lines represent the lead-lag correlation by original data and after eliminating Niño 4 SST impact, respectively. The dark dashed line represents the 95\% confidence level by t-test. 


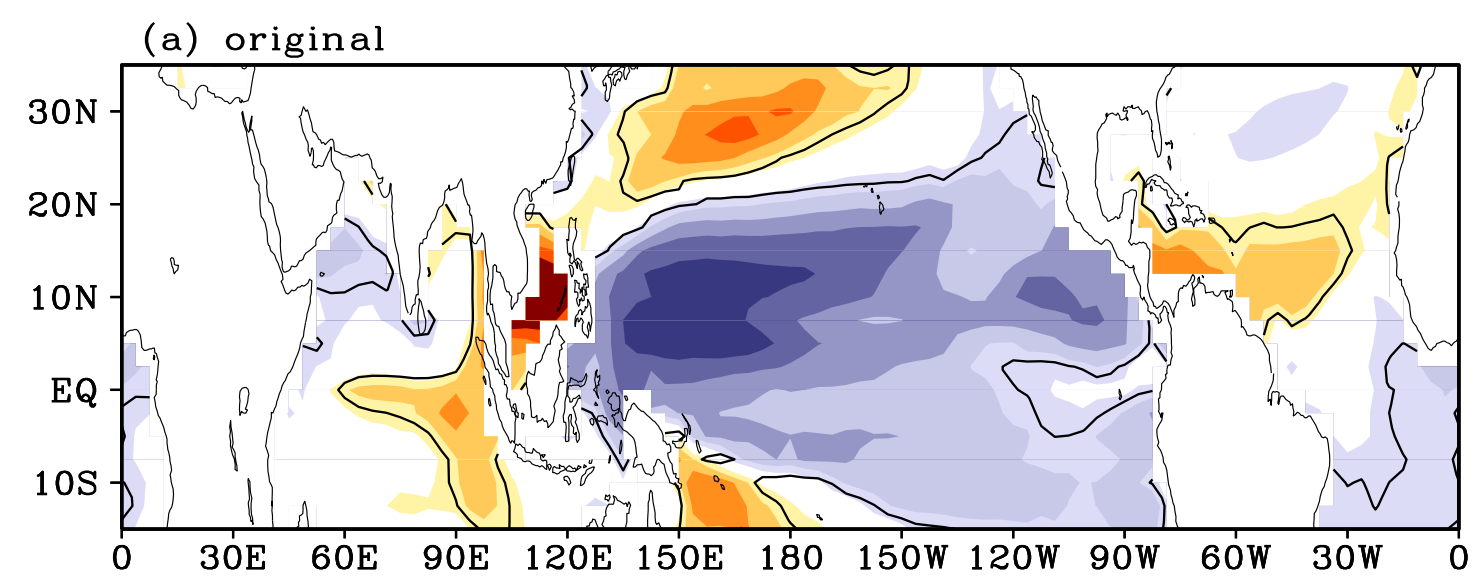

(b) remove Nino4

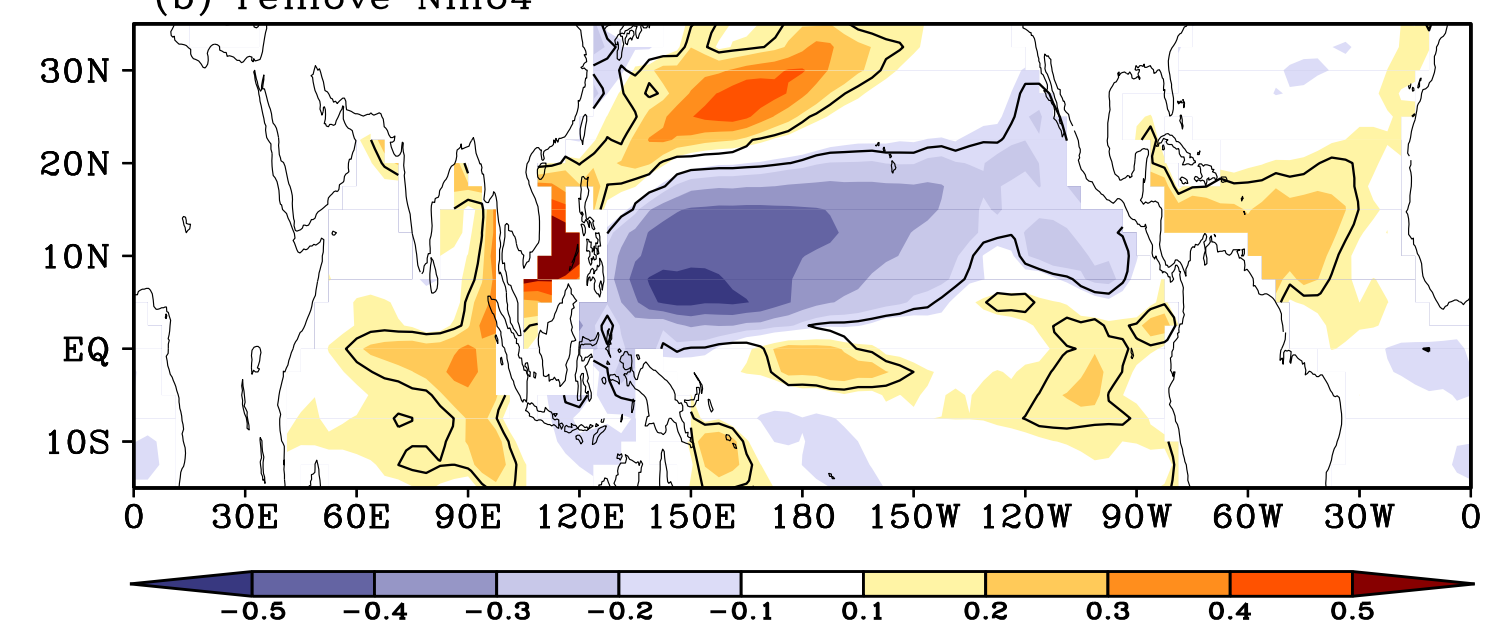

Fig. 4. Same as Fig. 1, but for the 160 years simulation of the CNTL. 


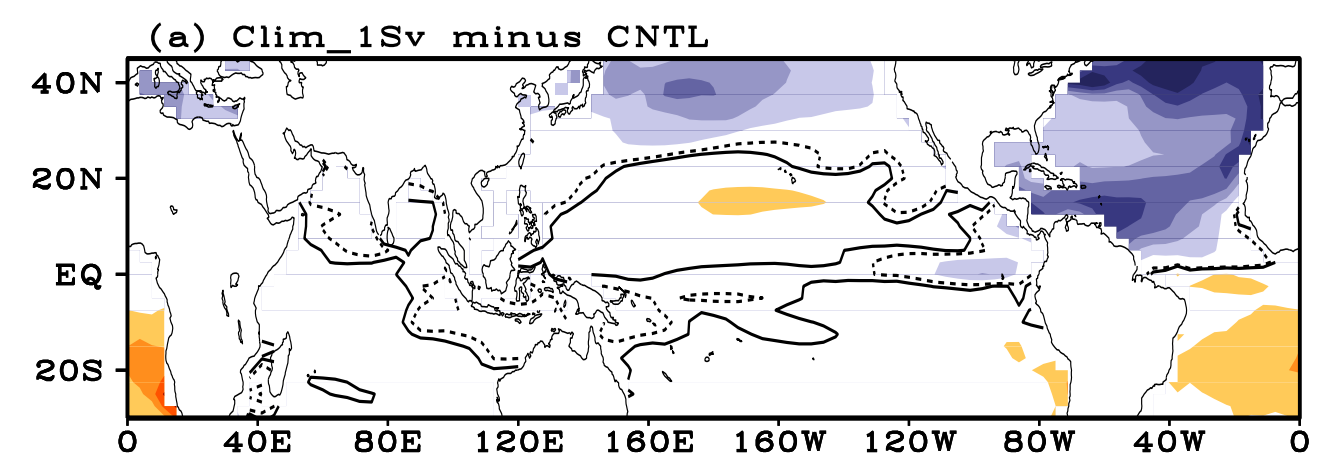

(b) Std_1Sv minus CNTL

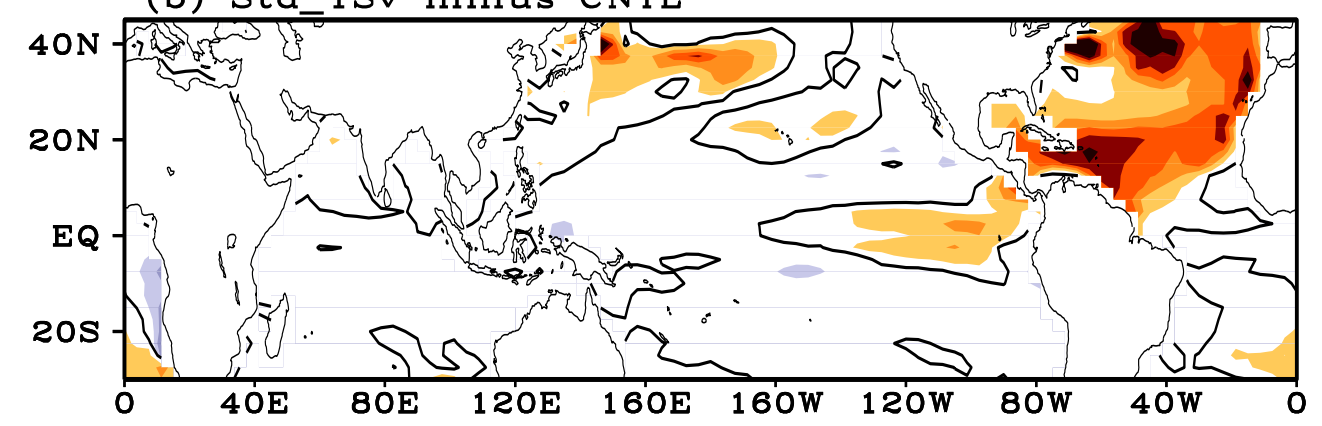

(c) Std(-Nino4) 1 Sv minus CNTL

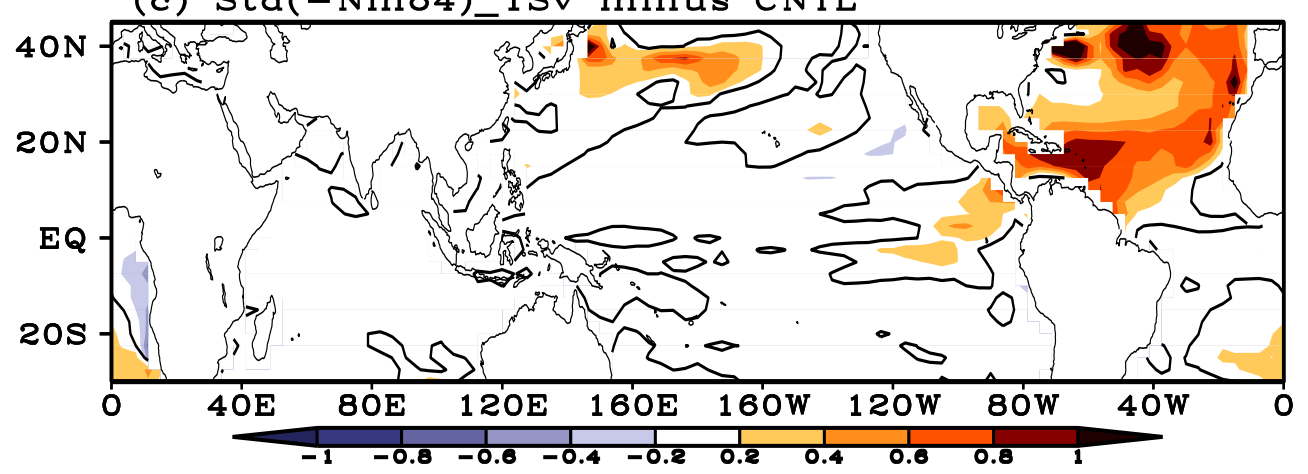

Fig. 5. Differences of climatological mean SST $\left({ }^{\circ} \mathrm{C}\right.$; a), interannual standard deviation of SST anomalies $\left({ }^{\circ} \mathrm{C} ; \mathrm{b}\right)$ and interannual standard deviation of SST anomalies after removing the Niño 4 index $\left({ }^{\circ} \mathrm{C}\right.$; c) in JJA between the $1 \mathrm{~Sv}$ and the CNTL. The regions within the black lines indicate where the differences are significant at $95 \%$ confidence level by $t$-test. 
(a) CNTL_SF850

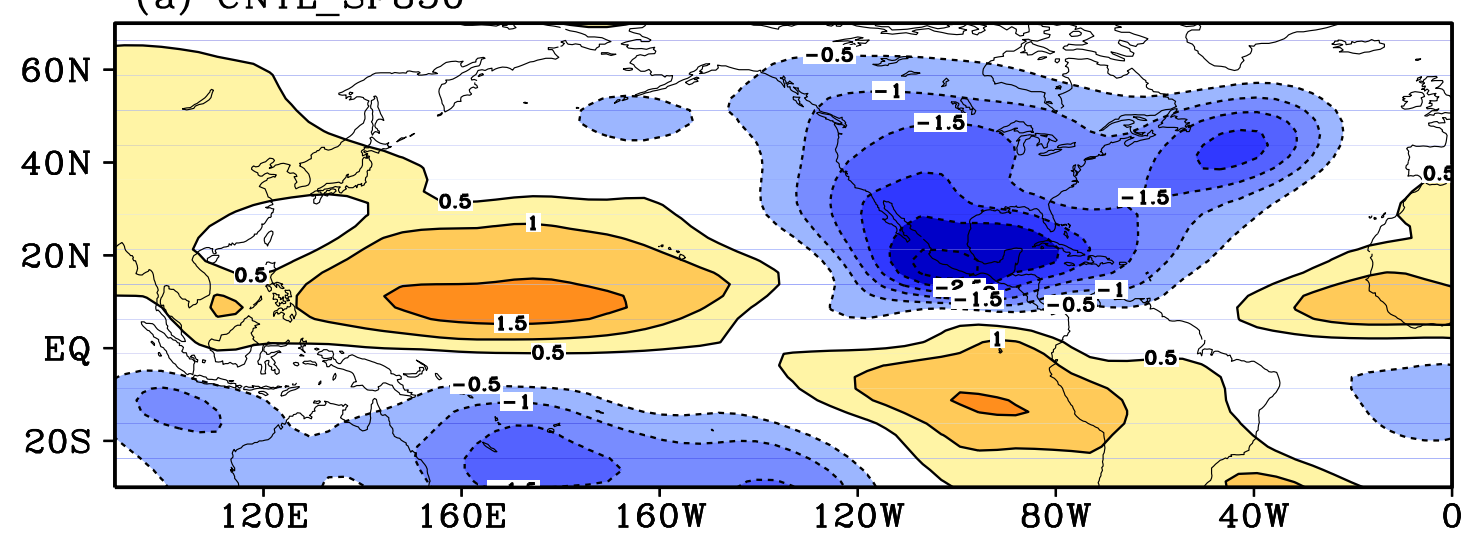

(b) $1 \mathrm{~Sv}$ SF850
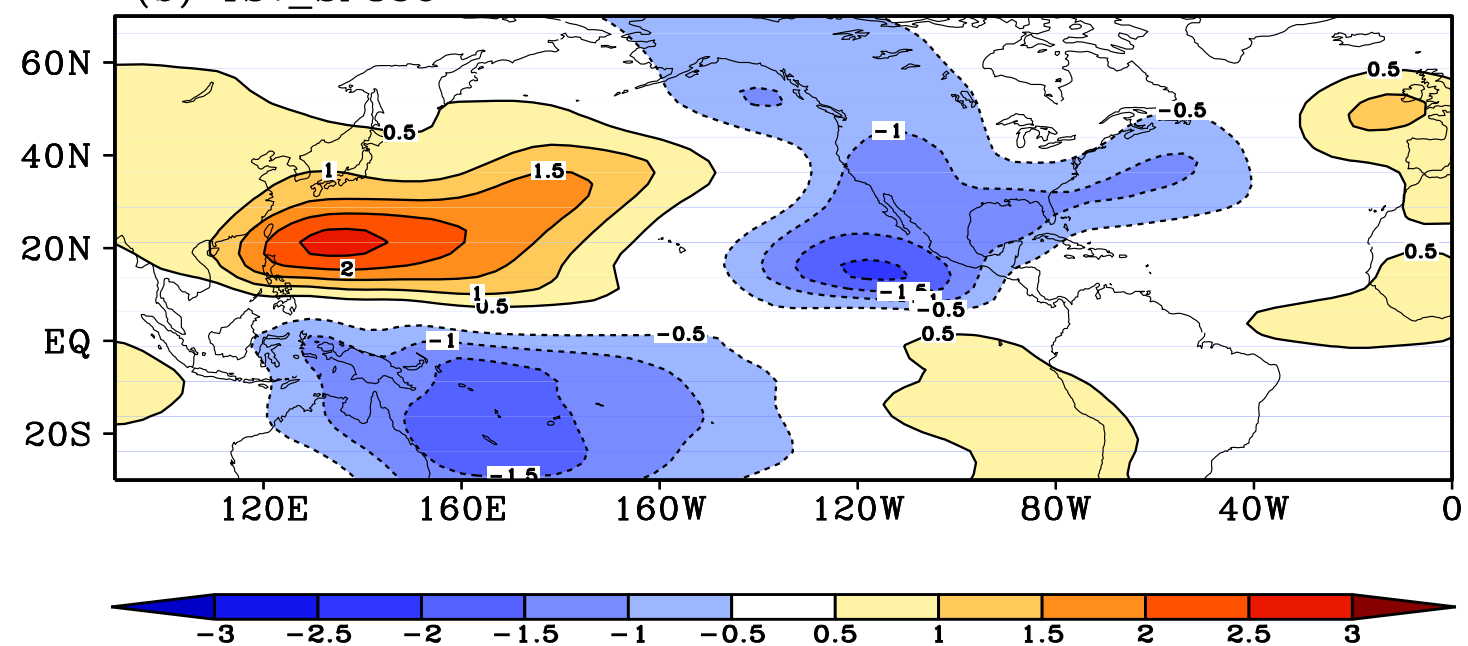

Fig. 6. Regression of $850-\mathrm{hPa}$ stream function anomalies $\left(10^{6} \mathrm{~m}^{2} \mathrm{~s}^{-1}\right)$ onto the TNA index in the CNTL (a) and the 1Sv (b). 
(a) CNTL_VP200

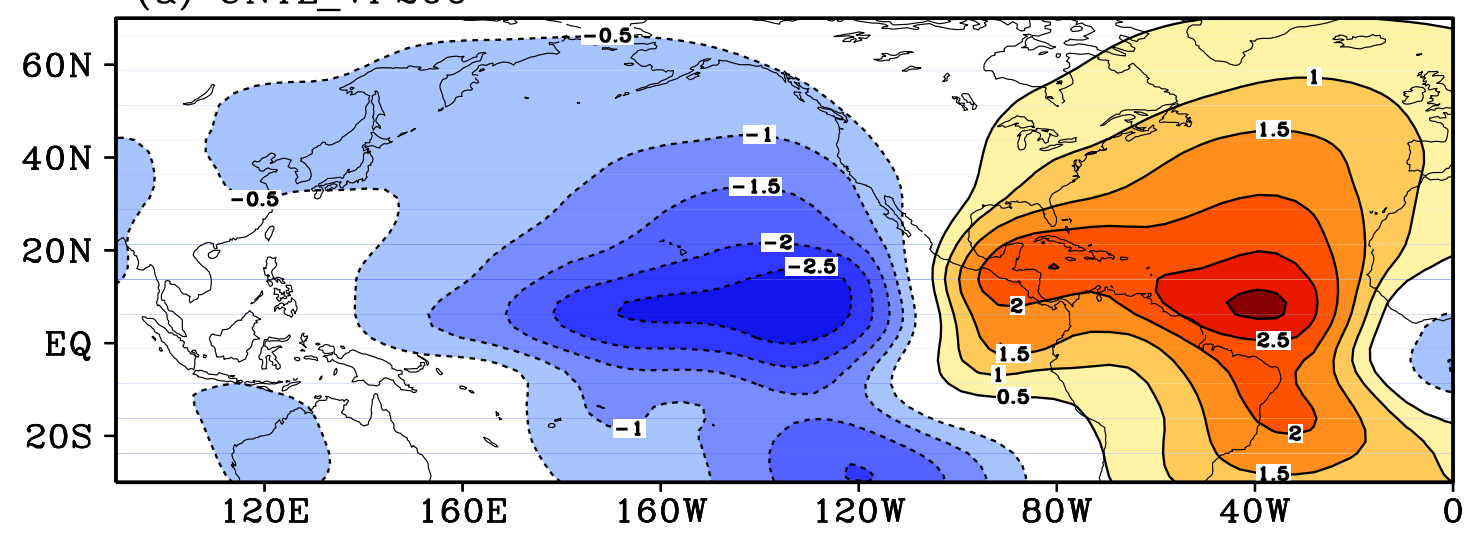

(b) $1 \mathrm{~Sv}$ VP200
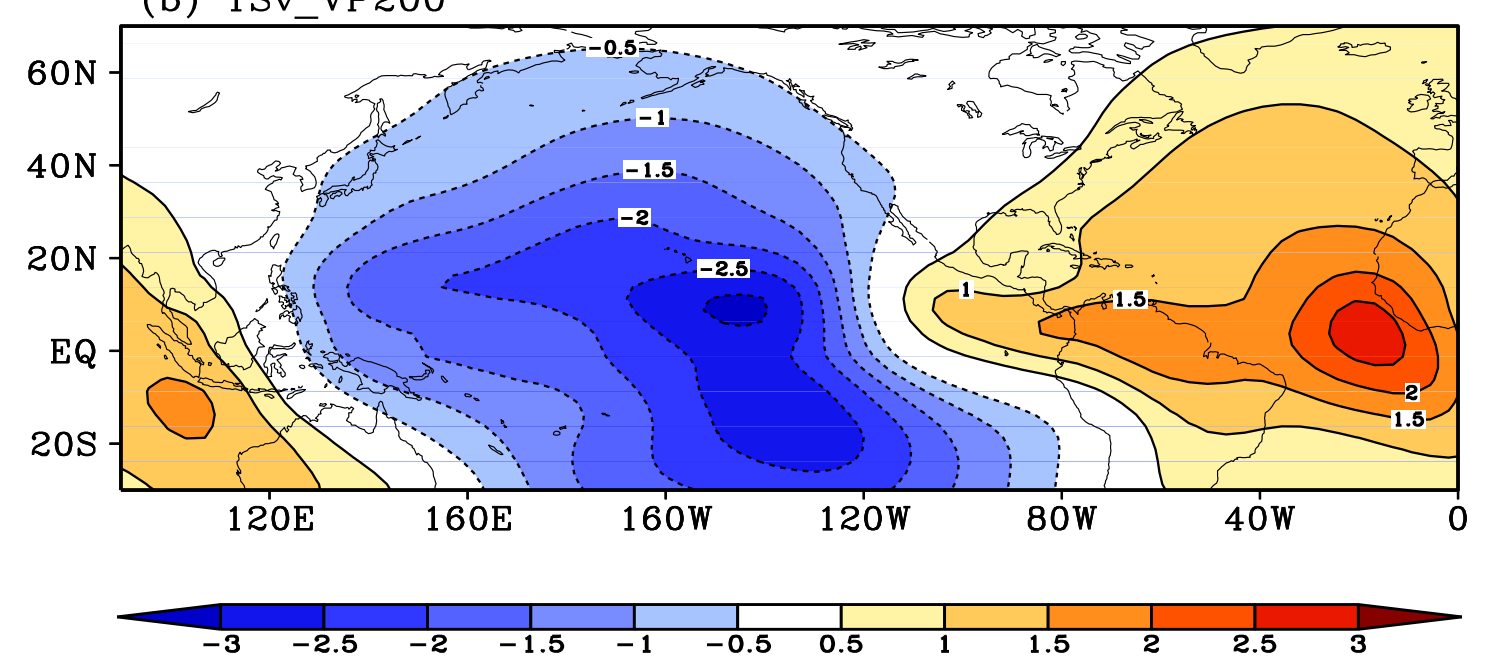

Fig. 7. Same as Fig. 6, but for the 200-hPa velocity potential anomalies $\left(10^{6} \mathrm{~m}^{2} \mathrm{~s}^{-1}\right)$. 
(a) CNTL_850hPa Wind\&Precip

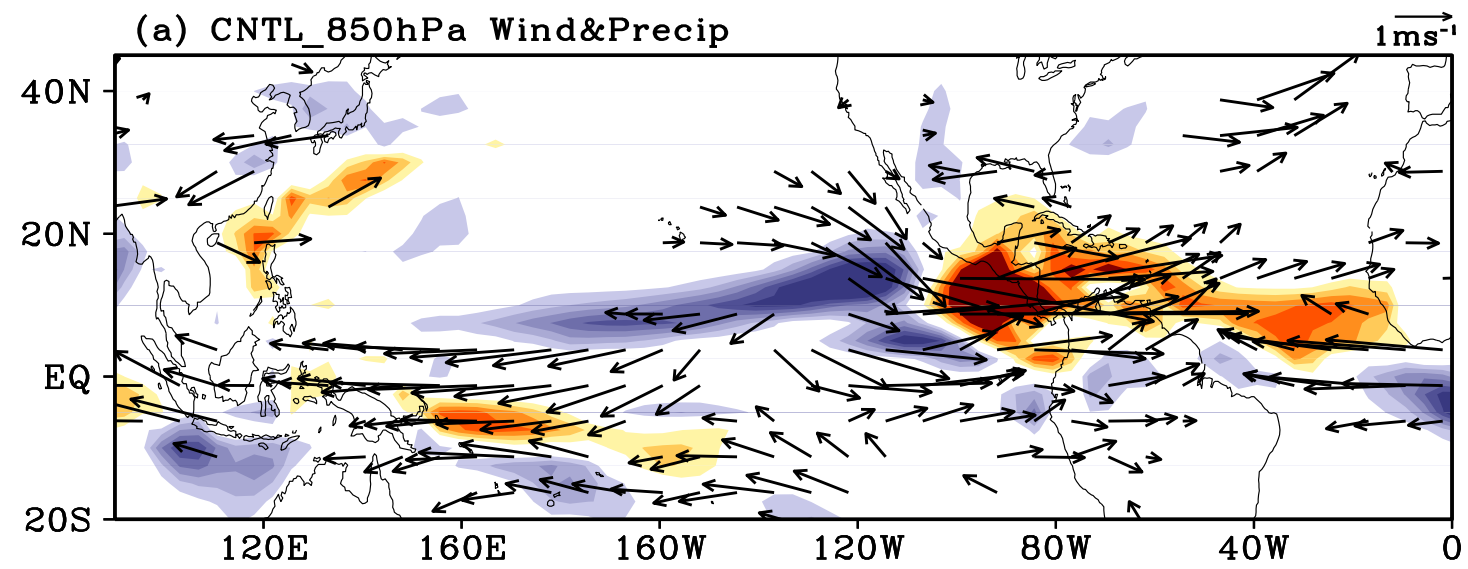

(b) $1 \mathrm{~Sv} \_850 \mathrm{hPa}$ Wind\&Precip
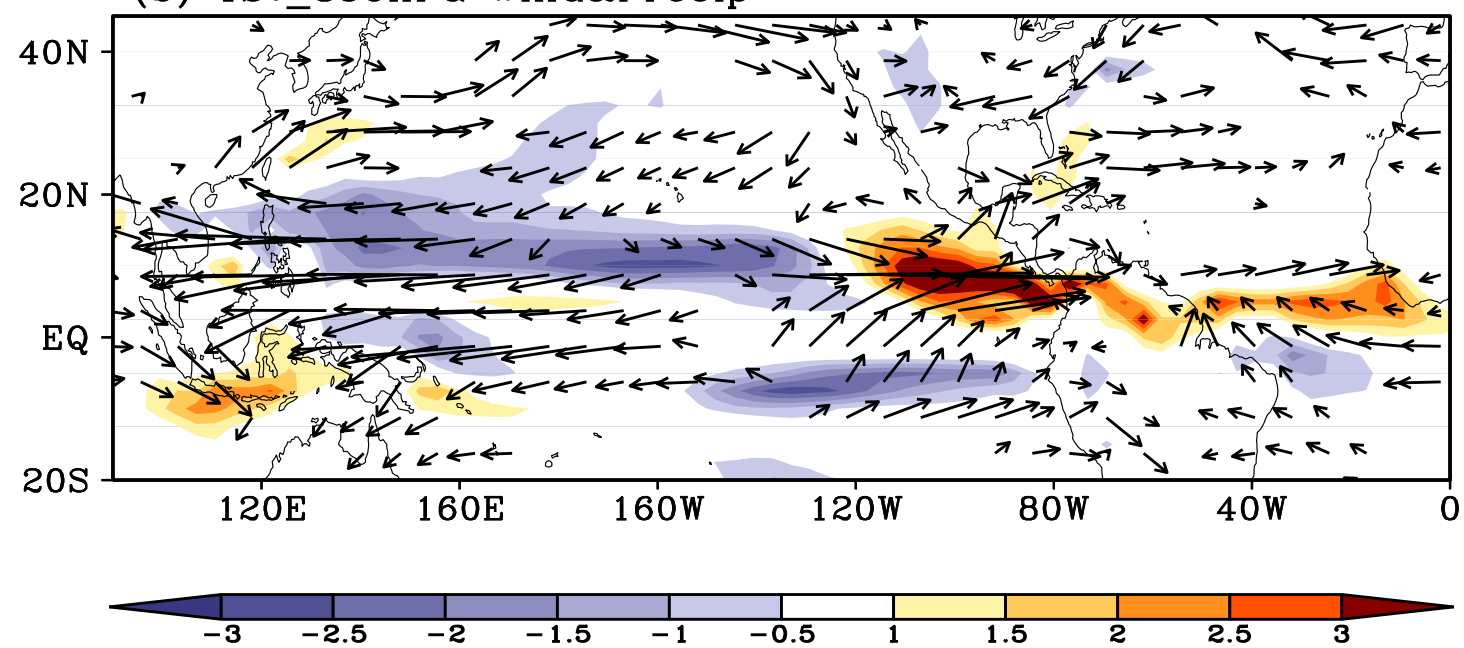

Fig. 8. Same as Fig. 6, but for the precipitation anomalies $\left(\mathrm{mm}\right.$ day $\left.^{-1}\right)$ and $850-\mathrm{hPa}$ wind anomalies. For $850-\mathrm{hPa}$ wind, only the anomalies are significant at $95 \%$ confidence level by F-test are shown. 
(a) CNTL_SST

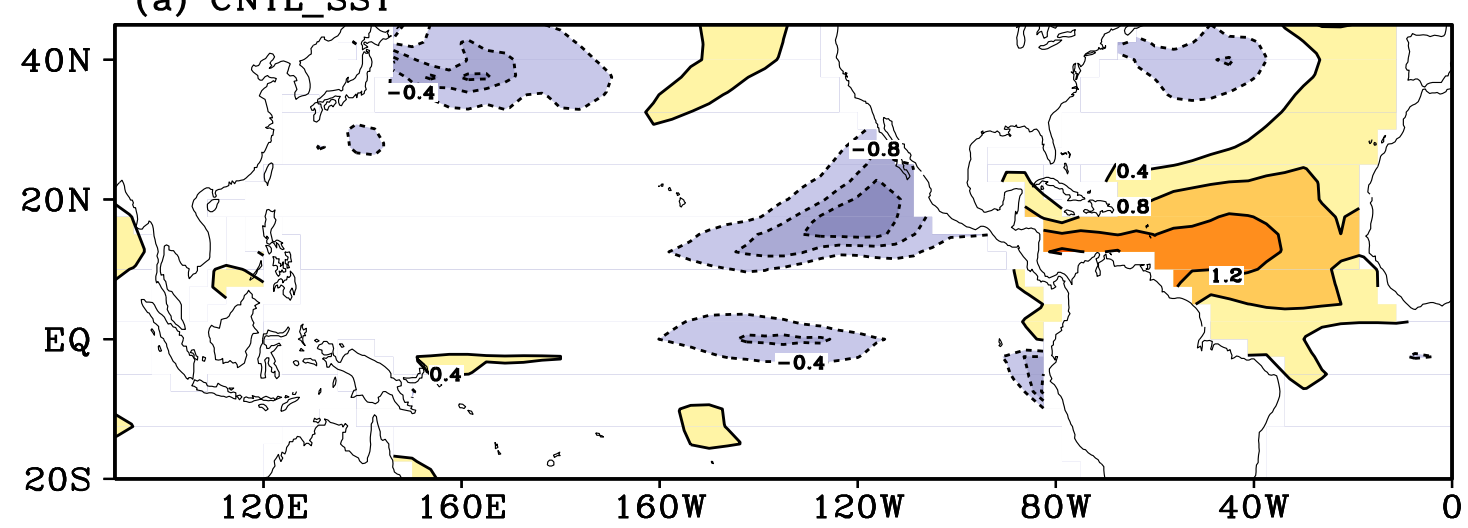

(b) 1Sv_SST

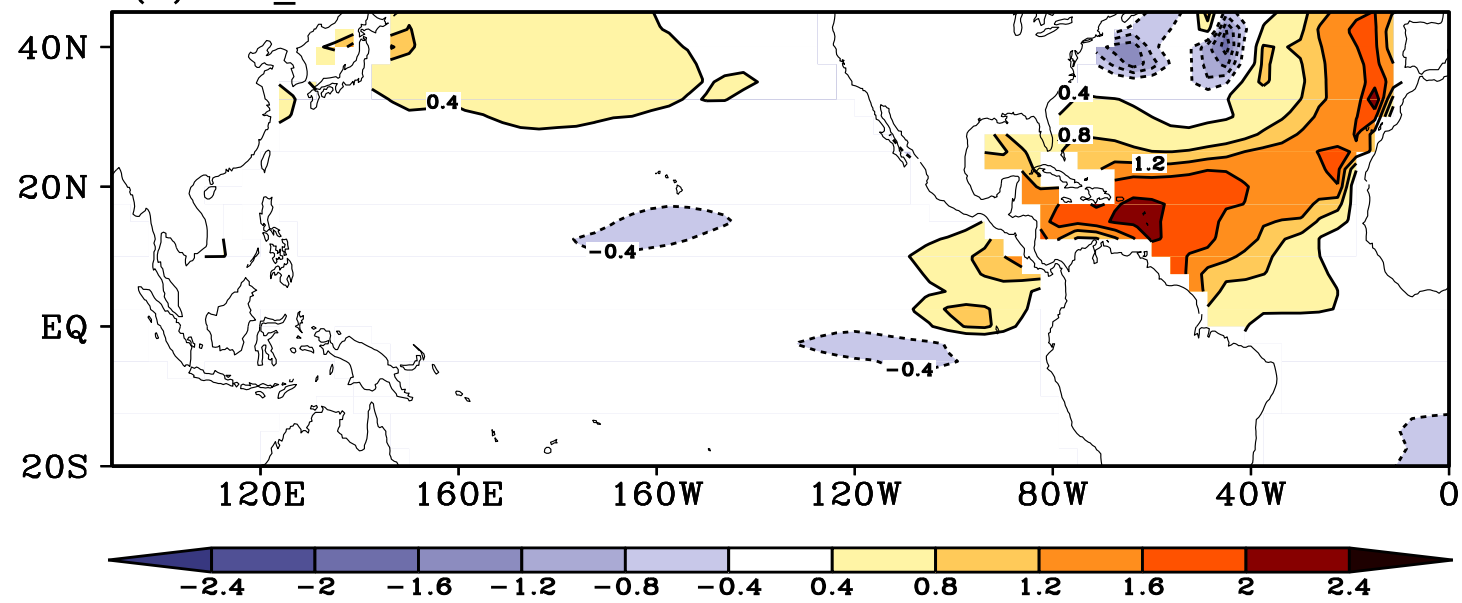

Fig. 9. Same as Fig. 6, but for the SST anomalies $\left({ }^{\circ} \mathrm{C}\right)$. 


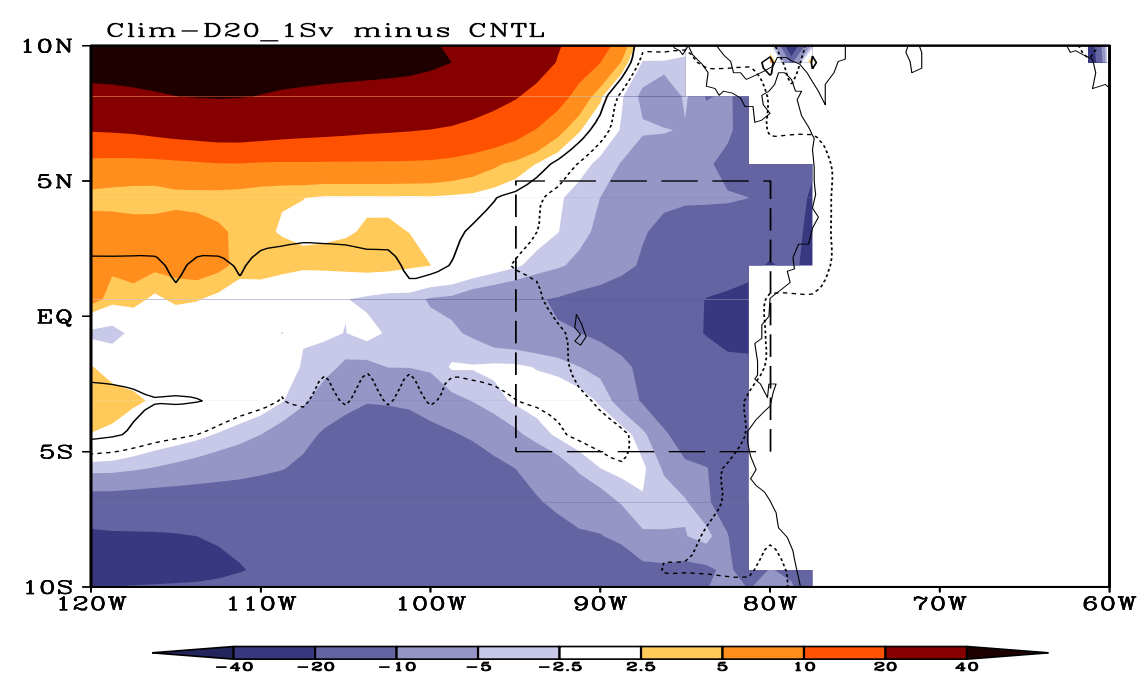

Fig. 10. Differences of climatological mean depth of $20^{\circ} \mathrm{C}$ thermocline (D20; $\left.\mathrm{m}\right)$ in JJA between the $1 \mathrm{~Sv}$ and the CNTL. The regions within the black lines indicate where the differences are significant at $95 \%$ confidence level by $t$-test. The dashed rectangle represents the region to calculate the difference of D20. 
(a) AMO - SF850

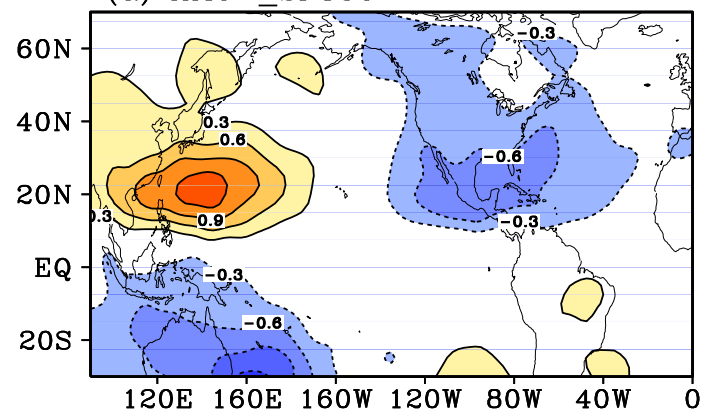

(b) $\mathrm{AMO}+\mathrm{SF} 850$

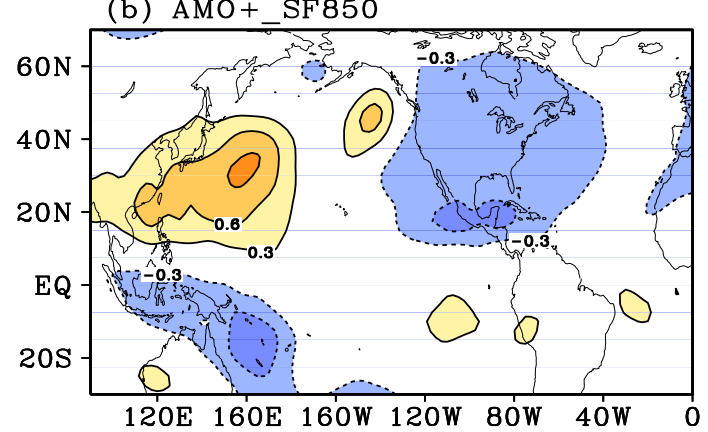

(c) AMO - VP2OO
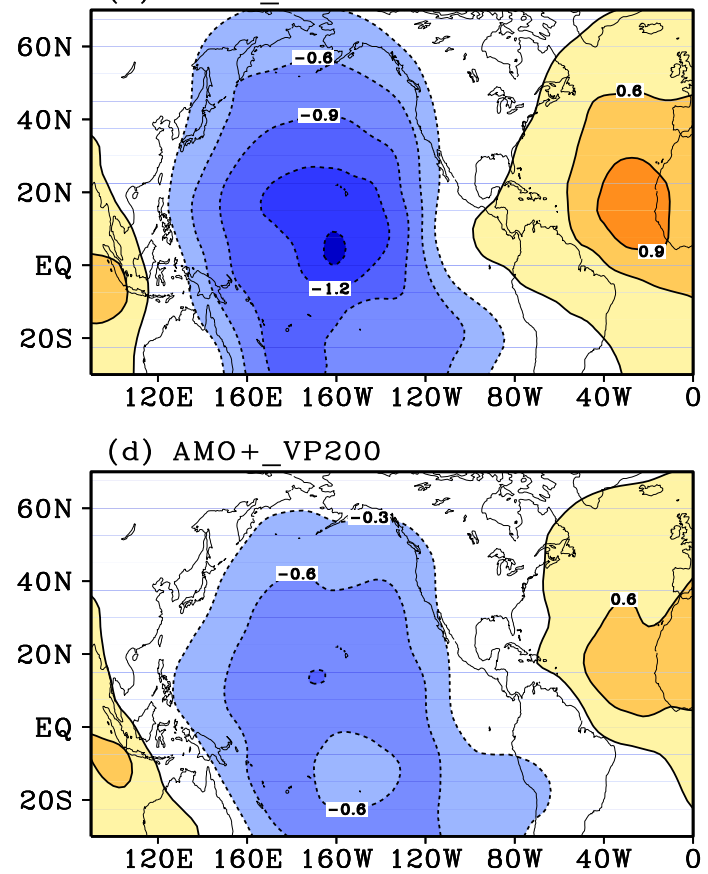

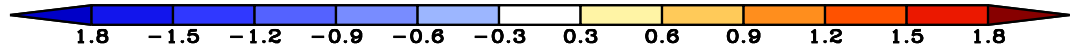

Fig. 11. Same as Fig. 6, but for the $850-\mathrm{hPa}$ stream-function anomalies $\left(10^{6} \mathrm{~m}^{2} \mathrm{~s}^{-1}\right.$; left panel) and 200-hPa velocity potential anomalies $\left(10^{6} \mathrm{~m}^{2} \mathrm{~s}^{-1}\right.$; right panel) during the negative phase of AMO (a, c) and the positive phase of AMO (b, d) in observations. 